2

9

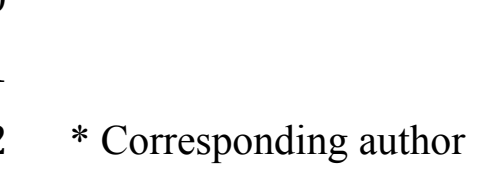

(1)

* Corresponding author

\section{Keywords:} 8

\section{Highlight:}

0 - First RSCM data for the Northern Apennines 3

\title{
RSCM THERMOMETRY IN THE ALPI APUANE (NW TUSCANY, ITALY): NEW CONTRAINTS FOR THE METAMORPHIC AND TECTONIC HISTORY OF THE INNER NORTHERN APENNINES
}

1) Dipartimento Scienze della Terra, Università di Pisa, Via S.Maria 53, 56126 Pisa, Italia

2) Sorbonne Université, Muséum National d'Histoire Naturelle, UMR CNRS 7590, IRD, Institut de Minéralogie, de Physique des Matériaux et de Cosmochimie, IMPMC, 75005 Paris, Francee

RSCM Thermometry, Thermal structure, Tectonics, Alpi Apuane, Northern Apennines

- Peak temperature in the Alpi Apuane metamorphic core and surroundings region

- New definition of the thermal structure and nappe architecture of the inner Northern Apennines 
ABSTRACT

In this study, Raman spectroscopy on carbonaceous material (RSCM) is applied, for the first time, in the Northern Apennines with particular focus on the Alpi Apuane (NW Tuscany, Italy) and surrounding areas in order to constrain peak metamorphic temperatures and their variability in the different continent-derived units of the nappe stack.

Peak temperatures in the range of $\sim 530-320{ }^{\circ} \mathrm{C}$ were found in the Alpi Apuane, whereas in the neareby metamorphic core of the Monte Pisano and Punta Bianca lower peak temperatures of 305$315{ }^{\circ} \mathrm{C}$ and $350{ }^{\circ} \mathrm{C}$ were found, respectively. The Tuscan Nappe in La Spezia area (west of Alpi Apuane) shows temperatures in the range of $295-246{ }^{\circ} \mathrm{C}$, whereas the same unit in the Lima Valley (east of the Alpi Apuane) shows temperatures lower than $230{ }^{\circ} \mathrm{C}$.

The collected data allowed refining the thermal architecture of the belt and the relationships between deformation (early and late folds and low angle normal detachments) and the metamorphic architecture of the Alpi Apuane core. These results provide new contraints for the thermomechanical evolution and exhumation history of the inner Northern Apennine and its geodynamic setting. In particular our data support the interpretation of the Alpi Apuane as a cold metamorphic core complex in which the preserved paleothermal structure and part of the exhumation are related with crustal thickening while the final exhumation stages (depth $\leq 15 \mathrm{Km}$ and at ambient crustal temperature $\leq 350^{\circ} \mathrm{C}$ ) are associated with crustal thinning still ongoing in the area.

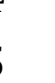

(2)

.




\section{Introduction}

73

74

The thermal structure and the field metamorphic gradient in mountain belts may be first order parameters directly related to the tectonic setting and the crustal-scale architecture of the orogens (between others Chopin et al., 1991; Hervegh and Pfiffer, 2005, Brown, 2009, Vitale Brovarone et al 2013, Agard and Vitale Brovarone, 2013 and references). Data on the thermal structure of metamorphic units combined with those constraining kinematic history delineates the extent to which heat and mass are transferred from mid to upper crust (e.g. Allemand, Lardeaux, 1997; Selverstone, 1988; Platt et al., 1998; Jolivet et al., 1998; Ring et al., 1999; Berger et al., 2011; Chen et al., 2011; Cottle et al. 2011; Bousquet et al., 2012). Therefore, the understanding of the thermal structure of the internal part of mountain belts is a key element to unravel the tectonic and kynematic frame of orogenic systems and the reconstruction of past geological boundary conditions as inputs for large-scale thermokinematic and geodynamics simulations (Aygüll et al., 2015; Beyssac et al., 2007; Simoes et al., 2007; Avouac et al., 2012; Scharf et al., 2013; Wiederkehr et al., 2011, Rosenberg et al., 2015).

The thermal characters of the inner Northern Apennines and the evolution of its main units were defined through a series of the classical methods including clay mineralogy, vitrinite reflectance, fluid inclusions and illite cristallinity for the shallowest units of the nappe stack (Cerrina et al., 1983; Carter and Dorwkin, 1990; Carosi et al., 2003; Reutter et al., 1978; Reutter et al., 1983; Ellero et al., 2001; Montomoli et al., 2001; Montomoli et al., 2002; Botti al., 2004; Dellisanti et al. 2010, Caricchi et al., 2014; Ventura et al., 2001), and Al-silicates, chloritoid-chlorite thermometry, calcite-dolomite, stable isotope geothermometers, and conodonts color in the lowermost metamorphic units (Franceschelli et al., 1986; Franceschelli et al., 1997; Franceschelli and Memmi, 1999; Molli et al., 2000a,b; Molli et al., 2002; Cortecci and Orlandi, 1975; Cortecci et al., 1994; Costagliola et al., 2002; Consani, 2002). More recently, thermodinamical modeling was also applied in the Paleozoic basement terms of the Tuscan metamorphic units (Lo Po' and Braga, 2014; Lo Po' et al., 2017).

Due to the patchy distribution of suitable rock types in the different units and within the nappe stack, however, we still lack a precise definition of the regional thermal structure and of the paleothermal field gradients. As a consequence the overall tectonic setting shaping the present day nappe-architecture is still a matter of debate, with crustal contractional and crustal extensional models being alternatively supported by different studies (Carmignani and Kligfield, 1990; Carmignani et al., 1994; Storti, 1995; Jolivet et al., 1998; Boccaletti et al., 1999; Carosi et al., 2003, 2004; Bonini and Sani, 2002; Brogi and Liotta, 2008; Thomson et al., 2010; Sani et al., 2014; 
Musumeci et al., 2015). This in turn leaves open some relevant questions, for instance the relationships between exhumation processes and the mode of crustal deformation (thickening vs. thinning) as well as the timing, thermal and structural record of crustal/litospheric stretching, which shaped characteristic features of the inner Northern Apennine in Tuscany such as the present day Moho depth and thermal anomaly (Carminati and Doglioni, 2012; Della Vedova et al., 2001; Di

111 Stefano et al., 2011; Spada et al., 2013 and references).

112 In this study, we present a regional-scale set of paleo-thermal estimates obtained by means of 113 Raman spectroscopy on carbonaceous material (RSCM), including a large range of lithologies from 114 the main units of the inner Northern Apennines, with special focus on the Alpi Apuane 115 metamorphic core and nearby areas. Thanks to the irreversible process of graphitization of 116 carbonaceuos material $(\mathrm{CM})$, this geothermometer can provide peak temperature $(\mathrm{T})$ estimates for 117 CM-bearing metasedimentary rocks independently from their mineralogical assemblage, and is 118 therefore aplicable to a wider range of rock types in the considered units compared to previous 119 studies.

120 Our data allow constraining the thermal structure and the exhumation-related paleogradients, 121 thereby improving our understanding of the orogenic processes recorded in the inner Northern 122 Apennines. Moreover, our data document the thermal architecture and metamorphic signature of a 123 mid-shallow orogenic wedge and its relationships with the regional structures, the nappe and thrust 124 stack styles and their internal deformation.

\section{Regional Geology}

The Northern Apennines (Fig.1) are characterized by a pile of thrust-sheets and fold nappes derived 130 from the distal part of the Adria continental margin (the Tuscan Domain), which presently rests 131 below the remnants of a former intraoceanic accretionary wedge represented by the Ligurian and 132 sub-Ligurian units relicts of the former Mesozoic western alpine Tethys ocean (Elter, 1975; 133 Marroni and Pandolfi, 1996; Bortolotti et al. 2001, Bernoulli, 2001; Butler et al., 2006; Molli, 2008; 134 Malavieille et al., 2016; Schmid et al., 2017). The recent to active tectonic framework of the 135 Northern Apennines is characterized by crustal-scale extension in the inner-western (Tyrrhenian) 136 side of the orogen, and shortening in its external eastern side (Po Plain and Adriatic) (e.g. Elter et 137 al., 1975; Barchi et al., 1998; Doglioni et al., 1998; Liotta, 2002; Bennett et al., 2012; Cuffaro et al., 138 2010; Eva et al., 2014; Faccenna et al., 2014; Molli et al., 2016; Le Breton et al., 2018).

139 In the NW of Tuscany, the Alpi Apuane complex forms the largest tectonic window in the inner 
140 Northern Apennines and expose the deepest crustal units of the belt (Tuscan Metamorphic Units) 141 (Fig.1). Three major stratigraphic and tectono-metamorphic units are traditionally distinguished in 142 the region, the Tuscan Nappe, the Massa unit and the Apuane unit, all derived from the Adria 143 continental paleomargin (Fig.2). The Tuscan Nappe consists of Mesozoic carbonate rocks and 144 Tertiary deep water and turbiditic sequences mainly detached from their original basement along 145 the décollement level of the former Carnian and Norian evaporites (Ciarapica and Passeri, 2002 146 and references therein). These anydrites and dolostones are transformed almost everywhere (with 147 some relevant exceptions) into cataclastic breccias called Calcare Cavernoso or "cellular" limestone 148 (Baldacci et al., 1967; Gandin et al., 2000). The post-Norian sequence continues with Rhaetian to 149 Hettangian shallow water limestones (Rhaetavicula Contorta and Calcare Massiccio), Lower Liassic 150 to Cretaceous pelagic limestones, radiolarites and shales (Calcare selcifero, Marne a Posidonomya, 151 Diaspri, Maiolica), grading to hemipelagic deposits of the Scaglia (Cretaceous-Oligocene), to end 152 with the siliciclastic foredeep turbidites of the Macigno (Late Oligocene-Early Miocene). The entire 153 sequence has a thickness between 2000 and 4000 m (Fazzuoli et al., 1986; Ciarapica and Passeri, 154 2002; Molli and Meccheri, 2012).

155 The Apuane Unit forming most of the Alpi Apuane tectonic window is made up of a Paleozoic 156 basement unconformably overlain by an Upper Triassic-Oligocene metasedimentary sequence. The 157 Paleozoic basement is represented by metasedimentary and metavolcanic rocks including Upper 158 Cambrian-Lower Ordovician phyllites and quarzites, Middle Ordovician metavolcanics and 159 metavolcanoclastics, Upper Ordovician quartzitic metasandstones and phyllites, Silurian black 160 phyllites and Orthoceras-bearing metadolostones (Gattiglio et al., 1989; Conti et al., 1993; Pandeli 161 et al., 1994; Paoli et al., 2017). The Paleozoic lithostratigraphic units were deformed and 162 metamorphosed under low-grade conditions, not well precisely defined, during the Variscan 163 orogeny (Conti et al., 1991, 1993). The Mesozoic cover-rocks, where complete, include thin 164 Triassic continental to shallow-water Verrucano-like deposits followed by Upper Triassic-Liassic 165 carbonate platform metasediments comprising dolostone (Grezzoni Fm.), dolomitic marble, and 166 marble (the Carrara Marble), in turn covered by Middle Liassic-Lower Cretaceous cherty 167 metalimestone, cherts, and calcschists, and Lower Cretaceous to Lower Oligocene sericitic phyllites 168 and calcschists with marble interlayers. Oligocene-early Miocene (?) metasediments related to 169 turbiditic systems (Pseudomacigno Fm.) complete the sedimentary succession (Patacca et al., 2011 170 and reference therein).

171 The Massa unit is exposed in the westernmost part of the Alpi Apuane complex and includes a 172 litho-stratigraphic sequence formed by a Paleozoic basement similar to that of the Apuane unit and 173 a characteristic and distinctive Upper Permian-Upper Triassic metasedimentary succession, 
including a Mid Triassic continental (conglomerates and pelites) to marine (carbonate platform 175 derived deposits) succession associated with intraplate alkaline basalts (Martini et al, 1985). 176 Lithostratigraphic terms younger than late Mid Triassic are not described in the literature, although 177 (see below) they are be locally found as tectonic lenses and small-scale remnants within a 178 cataclastic fault zone below the contact with the overlaying Tuscan Nappe (Molli et al., 2002; Conti 179 et al., 2004). Based on the similarities in stratigraphic contents of the pre-Late Triassic sequences, 180 traditional literature correlated the P.Bianca and M.Pisano exposures to those of the Massa unit 181 (Baldacci et al., 1967; Elter, 1975), whereas more recent papers defined different peak metamophic 182 conditions (Storti, 1995; Leoni and Pertusati, 2003; Carosi et al., 2004; Molli, 2008).

183 The deformation structures of the Tuscan metamophic units of the Alpi Apuane and surroundings 184 metamorphic cores may be referred to two main tectono-metamorphic regional events (D1 and D2 185 phases of Carmignani and Kligfield, 1990), which are regarded (Molli et al., 2000, 2002) as 186 recording progressive deformation of the distal Adriatic continental margin during continental 187 subduction and the syn- to post-contractional exhumation (Carmignani et al., 1990; Jolivet et al., 188 1998; Carmignani et al., 2001; Molli, 2008). The two main regional events D1 and D2 were related 189 to different fold generations as illustrated by Molli and Meccheri (2012). The same deformation 190 patterns may be also recognized in the Punta Bianca and Monte Pisano metamorphic cores (Storti, 191 1995; Montomoli, 2002; Carosi et al., 2007; Molli, 2008; Balestrieri et al., 2011).

192 Deformation event D1, which can be associated with underplating and antiformal stacking of the 193 metamorphic units, is defined by a main axial-plane foliation of isoclinal folds observable on a 194 micro- to kilometer-scale (Fig. 2) and is associated with a regionally NE-oriented stretching 195 lineation interpreted as recording the main transport direction of the inner Northern Apennines 196 (Carmignani et al., 1978; Molli, 2008; Molli and Meccheri, 2012).

197 During deformation D2, the previously formed structures were reworked by different generations of 198 folds and high-strain zones, related to exhumation of the metamorphic units within the inner portion 199 of the Northern Apenninic wedge (Molli, 2008). Characteristic structures of D2 event, are the late 200 folds with subhorizontal axial plane crenulation, later deformed by semibrittle and brittle structures, 201 represented by kink and open folds, and low-angle normal faults (Molli and Meccheri, 2000; Molli 202 et al., 2010). The final stages of deformation are recorded by systemes of high-angle normal to 203 oblique-normal and trascurrent faults related with the recent to active deformation regime affecting 204 the area (Corti et al., 2006; Bennett et al., 2012; Molli et al., 2016).

205 In the metamorphic units of the Alpi Apuane, peak conditions are roughly related to $\mathrm{T}$ between 450 206 and $350{ }^{\circ} \mathrm{C}$ and $\mathrm{P}$ of 0,8-0.4 GPa (Molli et al., 2002 and references therein). In particular, kyanite + 207 chloritoid + phengitic muscovite chracterize the mineral assemblages in metapelites of the Massa 
unit, with peak conditions estimated in the range of $0,6-0,8 \mathrm{GPa}$ and $420-500^{\circ} \mathrm{C}$ (Franceschelli et al., 1986; Jolivet et al., 1998; Franceschelli and Memmi, 1999; Molli et al., 2000b). Instead, pyrophyllite + chloritoid + chlorite + phengitic muscovite in metapelites are found in the Apuane

211 unit, with peak metamorphic conditions estimated in the range of 0.4-0.6 GPa and 350-450 ${ }^{\circ} \mathrm{C}$ 212 (Franceschelli et al., 1986; Jolivet et al., 1998; Molli et al., 2000b).

213 The early deformation D1 in the metamophic units of the Alpi Apuane occurred during early 214 Miocene at 27-20 Ma (Kligfield et al., 1986), whereas the syn-metamorphic D2 structures 215 developed at $\mathrm{T}$ higher than $250^{\circ} \mathrm{C}$, predated $11 \mathrm{Ma}$ according to zircon fission-track ages of Fellin 216 et al. (2007).

217 In contrast to the Tuscan metamorphic units, the Tuscan nappe was accreted at a shallow crustal 218 level within the Northern Apennines wedge beginning from early Miocene (Cerrina Feroni et al., 219 1983; Molli, 2008). Burial occurred under a sequence of thrust sheets now preserved in the 220 overlying sub-Ligurian and Ligurian units (Figs. 1, 2). Early thrusting is documented by top-to-the 221 east small scale shear zones and an early generation of east vergent tight to isoclinal folds within 222 incompetent stratigraphic layers (Gianmarino and Giglia, 1990; Carter and Dworkin 1990; Molli et al., 2011). The early structures in the Tuscan nappe were subsequently overprinted by small to large (kilometer-scale) refolding associated with sub-horizontal crenulation cleavage observable in pelitic rock units, low-angle normal faults and later upright folds (Carmignani et al., 1994; Storti, 1995; Carosi et al., 2003). Metamorphism to anchizone grade (Cerrina Feroni et al., 1983; Carosi et al., 2003; Molli et al., 2011) during burial and deformation is constrained by tectono-stratigraphic features to a maximum depth of $7 \mathrm{~km}$ for the Macigno sandstones (Reutter et al., 1978; Montomoli et al., 2001; Montomoli, 2002; Fellin et al., 2007).

\section{Raman Spectroscopy of Carbonaceous Material}

Raman spectra were obtained using a Renishaw InVIA Reflex microspectrometer (IMPMC Paris). We used a $514 \mathrm{~nm}$ Laser Physics argon laser with circular polarization. The laser was focused on the sample by a Leica microscope with a $100 \times$ objective $(\mathrm{NA}=0.85)$, and the laser power at the sample surface was set around $1 \mathrm{~mW}$. The Rayleigh diffusion was eliminated by edge filters, and to achieve nearly confocal configuration the entrance slit was closed down to $15 \mu \mathrm{m}$. The signal was finally dispersed using a $1800 \mathrm{gr} / \mathrm{mm}$ grating and analyzed by a Peltier cooled RENCAM CCD detector. Before each session, the spectrometer was calibrated with a silicon standard. Because Raman spectroscopy of CM can be affected by several analytical mismatches, we closely followed 
242 the analytical and fitting procedures described by Beyssac et al. (2002, 2003). Measurements were 243 done on polished thin sections cut perpendicularly to the main fabrics and CM was systematically 244 analyzed below a transparent adjacent mineral, generally quartz. Between 10-20 spectra were 245 recorded for each sample in the extended scanning mode (1000-2000 cm-1) with acquisition times 246 from 30 to $60 \mathrm{~s}$. Spectra were then processed using the software Peakfit (following Beyssac et al., 247 2002). Based on the obtained spectra, T from samples characterized by lower-T metamorphism (i.e. $248 \sim 200 \leq \mathrm{T} \geq 350^{\circ} \mathrm{C}$ ) were estimated.

249 Both low-grade $\left(<350^{\circ} \mathrm{C}\right)$ and high-grade $\left(>350^{\circ} \mathrm{C}\right)$ were considered. In the former case, RSCM T 250 was estimated using the correlation proposed by Lahfid et al. (2010) for the T range of $\sim 200 \leq \mathrm{T} \geq$ $251350{ }^{\circ} \mathrm{C}$. In the latter case, the $\mathrm{T}$ was calculated using the calibration of Beyssac et al. (2002) for a $\mathrm{T}$ 252 range of $\sim 350 \leq \mathrm{T} \geq 650{ }^{\circ} \mathrm{C}$. Both calibrations have an attached accuracy of $\pm 50{ }^{\circ} \mathrm{C}$ due to 253 uncertainties on petrologic data used for the calibration. Relative uncertainties on $\mathrm{T}$ are, however, 254 much smaller, around $10-15^{\circ} \mathrm{C}$ (Beyssac et al., 2004).

255 For each sample, several spectra were acquired to assess the potential within-sample structural 256 heterogeneity, with the exception of a few samples containing very little CM amount (Table 1). The latter samples have therefore higher uncertainty compared to the others, and were not considered for tectonic interpretations even though the obtained $\mathrm{T}$ is in the range of the neighbouring ones. In a few samples, isolated spectra of crystalline graphite (no defect bands) were interpreted as detrital $\mathrm{CM}$ incorporated in the sedimentary rocks prior to metamorphism, and not considered for thermometric estimates. Some structural heterogeneity was found in the samples, with a maximum standard error (standard deviation devided by $\sqrt{ } \mathrm{n})<8$ for most samples (Table 1 ).

263 The Raman spectra obtained from the selected samples set show a large between-sample variation in structural organization ranging from poorly organized CM (lower-T) to well cristallized graphite (higher-T) (Table 1). The collected data allow distinguishing samples characterized by $\mathrm{T}$ gaps in the order of about $20{ }^{\circ} \mathrm{C}$ (Fig. 3), as already observed for this method along continuous metamorphic gradients in Alpine settings (Beyssac et al., 2004; Gabalda et al., 2009; Vitale Brovarone et al., 2014)

\section{RSCM Temperature record in the Alpi Apuane and sourroundings}

Seventyfour samples were selected for RSCM analysis among 120 collected in various stratigraphic and structural positions within the different tectonic units (Table 1). The samples were collected along a regional SW-NE oriented section across the inner Northern Apennines (Fig. 1). The 
uppermost continental unit of the nappe pile was sampled west of the Alpi Apuane in the La Spezia area (Fig. 1,2), where the stratigraphic sequence of the Tuscan Nappe is exposed in different localities, from Portovenere (southern tip of western promontory of La Spezia) northward to the 5 Terre area as part of a regional-scale fold called La Spezia fold (e.g. Gianmarino and Giglia, 1991; Carter, 1992; Carosi et al., 2002; Molli et al., 2011 and references therein), in the eastern promontory of La Spezia (between Lerici and Punta Bianca) (Storti, 1995; Clemenzi et al., 2015 and references), north and east of the Alpi Apuane in the Lunigiana and Lima Valley (Molli et al., 2015; Clemenzi et al., 2014 and references).

A more systematic sampling was performed across the Alpi Apuane in order to enlighten the thermal structure of the metamorphic core that was poorly documented so far (Figs. 2,4 and Table 1). Some samples of the metamorphic units were also collected in the eastern promontory of La Spezia as well as southeastward of the Alpi Apuane in the Monte Pisano (Fig. 2).

The stratigraphic units sampled in our study are mainly from the Mesozoic to Tertiary cover sequence and in particular from siliciclastic sandstones of Macigno fm. (Late Oligocene-Early Miocene in age) and impure Triassic limestones for the Tuscan Nappe. The metamorphic equivalents (metasandstones, slates, schists, calcschists and impure marbles) were sampled in the Apuane and Massa units, together with some samples from the Paleozoic basement units (mainly phyllites and schists) (Fig. 2). The samples collected in the eastern promontory of La Spezia come from the Triassic impure limestone at the base of the Tuscan Nappe and from the underlying preMesozoic terms (black phyllites supposed to be Permian age) of the metamorphic Punta Bianca unit i.e. respectively in the hanging-wall and footwall of the former major thrust reworked as a low angle normal fault (Storti, 1995; Carosi et al., 1998, Clemenzi et al., 2015). Moreover, the two analyzed samples in the Santa Maria del Giudice unit are part of the Monte Pisano metamorphic core (Rau and Tongiorgi, 1974; Carosi et al., 1993; Montomoli, 2002; Leoni et al., 2009) and are derived from its Tertiary cover sequence (Pseudomacigno Fm.).

Results are presented in maps and projected along the SW-NE structure-orthogonal regional and local cross sections (Figs. 4, 5, 6). For the sake of comparison, results of previous studies including

The sampling strategy allowed constraining RSCM T within the classically defined continentderived units of the inner Northern Apennines (Elter, 1975; Carmignani et al., 1978; Carmignani and Kligfield, 1990; Carmignani et al., 2001 between the others) which are in the current view (see 
and Apuane (also called "Authochtonous") units (Fig. 1). In the La Spezia area, the Punta Bianca metamorphic occurences are associated with a pristine lithostratigraphic assemblage similar to that of the Massa unit but affected by a lower grade peak metamorphic imprint (Storti, 1996; Leoni and 313 Pertusati, 2003; Lo Po' et al., 2017), whereas the Monte Pisano metamorphic core is similarly 314 considered part of the Massa unit for the presence of widespread continental "Verrucano" deposits 315 (Rau and Tongiorgi, 1974; Carosi et al., 2004; Balestrieri et al. 2011).

The overall data sets, summarized in Fig. 7 and Table 1, show significant difference in mean peak T among the major tectonic units so far defined. RSCM peak T are in the range of $246-284{ }^{\circ} \mathrm{C}$ (mean $260 \pm 26^{\circ} \mathrm{C}$ ) for the Tuscan Nappe; $306-537^{\circ} \mathrm{C}$ (mean $397 \pm 64{ }^{\circ} \mathrm{C}, \mathrm{n}=63$ ) for for the Apuane and $454-509^{\circ} \mathrm{C}\left(485 \pm 28^{\circ} \mathrm{C}, \mathrm{n}=3\right)$ for the Massa unit.

In the Tuscan Nappe exposed in the La Spezia area (Figs. 1,2), a simple relationship between stratigraphic positions of the samples and peak T appears (Fig. 6). The youngest terms of the succession represented by the Macigno fm. show a mean $\mathrm{T}$ of $253{ }^{\circ} \mathrm{C}$, whereas in the lowermost measured Triassic term of the Calcari a Rhaetavicula Contorta fm. (Rhaetian in age) a mean $\mathrm{T}$ of $289^{\circ} \mathrm{C}$ was obtained.

In the eastern Promontory of La Spezia in the same stratigraphic unit i.e. the Calcari a Rhaetavicula Contorta (Rhaetian in age), a mean $\mathrm{T}$ of $\sim 284{ }^{\circ} \mathrm{C}$ well confirmed the $\mathrm{T}$ obtained in the same stratigraphic unit in the western promontory.

Samples from the Tuscan Nappe in the Lima Valley (Baldacci et al., 1967; Fazzuoli et al. 1994; Botti et al., 2009; Clemenzi et al., 2014) east of the Alpi Apuane show instead lower mean temperature of $227^{\circ} \mathrm{C}$ obtained for Jurassic and Cretaceous pelites and marls (Table 1, Fig. 6).

In the Alpi Apuane, although the highest $\mathrm{T}$ were measured in samples of the Paleozoic basement (364-537 ${ }^{\circ} \mathrm{C}$, mean $445 \pm 66^{\circ} \mathrm{C}, \mathrm{n}=9$ ) and the lowest in the youngest stratigraphic terms of the cover sequence (PseudoMacigno fm.) $\left(306-511^{\circ} \mathrm{C}\right.$, mean $\left.368 \pm 50^{\circ} \mathrm{C}, \mathrm{n}=22\right)$, no simple relationships between stratigraphy and $\mathrm{T}$ appear at the scale of the whole metamorphic core (Figs. 4,5,8).

The mean $\mathrm{T}$ in the north-western part of the metamorphic complex (north of the Seravezza-Monte Corchia, Turrite valley alignment) is basically the same as those defined in the south-eastern segment (south of the Seravezza-Monte Corchia, Turrite valley alignment), around $\sim 380{ }^{\circ} \mathrm{C}$. The $\mathrm{T}$ data plotted on composite vertical cross-sections (Figs. 5,9) show, however, a well defined, yet different thermal structure and overall thermal architecture between the northern and southern Alpi Apuane. 
343 The north-western part of the Alpi Apuane, as previously defined, (cross-sections A,B,C,D,E,F,G) 344 shows an inverted field metamorphic gradient. Within the Apuane unit, higher T (483-507 ${ }^{\circ} \mathrm{C}$, mean $465^{\circ} \mathrm{C}$ ) are found to the west, within a structural distance of $\sim 500 \mathrm{~m}$ from the basal contact of the Massa unit (Figs. 5,9). The T decrease eastward and structurally downward to $\sim 345{ }^{\circ} \mathrm{C}$ in the Orto di Donna sincline and in the Arni-Boana structural culmination, i.e. in the geometrically deepest parts of the Alpi Apuane metamorphic core (Kligfield et al., 1981; Carmignani and Kligfield, 1990; Carmignani et al., 2001; Molli and Vaselli, 2006).

The south-eastern parts of the Alpi Apuane (cross-sections H,I,L,M) are instead characterized by a normal-type metamorphic field gradient with overall upward decreasing $\mathrm{T}$ from $510{ }^{\circ} \mathrm{C}$ to $320{ }^{\circ} \mathrm{C}$ in a vertical structural distance of $3000 \mathrm{~m}$.

Samples with the highest RSCM T are found in the south-eastern part of the Alpi Apuane, an area known in the local geological literature as "Zona dello Stazzemese" or "Stazzemese Shear Zone" (Stazzema is village included in it). The area is characterized and recognized for a long time for its distinctive structural style (see Massa 2007 for an historical ovierview) with kilometer scale recumbent D2 isoclinal folds with highly sheared and mylonitized limbs (see Carmignani et al. 1996, Conti et al., 2009; Cinquini, 2014). Samples characterized by the highest RSCM T are intimately related to mineralized bodies $(\mathrm{Pb}-\mathrm{Zn} \pm \mathrm{Au} \mathrm{Hg}, \mathrm{Fe}-\mathrm{Cu}$ and Barite-Iron Oxide-Pyrite deposits), characteristic of this area with respect to the whole Alpi Apuane and studied and exploited since the mid of last century (Carmignani et al., 1972; Carmignani et al., 1976; Orberger, 1985; Costagliola et al., 1990; Dini et al., 1995; Costagliola et al., 1998; Biagioni et al., 2016). This was observed in samples of different age (Palaeozic, Mesozoic and Cenozoic). Other samples from the Stazzemese Shear Zone but far away from these ore bodies show lower RSCM T. The RSCM T for these samples exceed of about $180-200{ }^{\circ} \mathrm{C}$ the values obtained for the enclosing host rocks. As an example, in the Fornovolasco area (the easternmost extension of the "Zona dello Stazzemese"), Tertiary metasandstones (Pseudomacigno Fm.) show RSCM T $>500^{\circ} \mathrm{C}$ (sample 70) if close to mineralized levels (Trimpello ore bodies), whereas the same rock type far from mineralized bodies shows $\mathrm{T}<360{ }^{\circ} \mathrm{C}$ (samples 68,69,71) (Fig. 5 and Table1). This feature suggests that the origin

\section{Comparison with previous data}

Our new RSCM data find good agreement with previous available data, in particular those derived 
2000; Oesterling et al., 2007). Although different in absolute value, the RSCM and Ca/Do data well document the presence of inverted metamorphism in the north-west part of the Alpi Apuane, with higher $\mathrm{T}$ in the westernmost and uppermost structural positions, decreasing eastward and downward within the structural building.

To the West (where the T are highest), Ca/Do shows lower values with respect to RSCM, whereas this is not always the case or is the opposite in the central and easternmost part of the Apuane (Fig.4).

The comparison between Ca/Do and RSCM cannot be drawn for the lack of data in the southeastern part of the Alpi Apuane ("Zona dello Stazzemese") where suitable rock-types for Ca/Do analyses are less common and therefore not deeply investigated in the literature. In this area, however, studies based on various techniques including stable isotope compositions and geothermometry, fluid inclusions and phase relationships between sulfosalts in ore bodies give host rock $\mathrm{T}$ around $350-400{ }^{\circ} \mathrm{C}$ and $\mathrm{T}$ for mineralizing fluids and ore bodies higher than $450{ }^{\circ} \mathrm{C}$ (Cortecci et al., 1989; Cortecci et al., 1994; Costagliola et al., 1997; Costagliola et al., 1998; Biagioni et al., 2013, 2016) which are similar to our RSCM results.

For the Massa unit, owing to intense wheatering and oxidation, only 3 out of 25 samples from Verrucano continental metasediments were analyzed. Our mean RSCM T is in agreement with the estimates based on Fe-Mg exchanges in coexisting chloritoid and chlorite $\left(450-500{ }^{\circ} \mathrm{C}\right.$; Franceschelli and Memmi, 1999). Similar T ranges were also constrained by the stability field of the kyanite+quartz pair and chlorite+chloritoid+quartz assemblages in the $\mathrm{FeO}-\mathrm{Al}_{2} \mathrm{O} 3-\mathrm{SiO}_{2}-\mathrm{H}_{2} \mathrm{O}$ (Franceschelli et al., 1998). Using similar methods chloritoid \pm chlorite $\mathrm{Mg} \pm \mathrm{Fe}$-exchange thermometer a peak temperature of $455{ }^{\circ} \mathrm{C}$ was found by Molli et al. (2000). Ca-Do data in the Mid-Triassic marble of the Massa unit also give a similar $\mathrm{T}$ in the range of $430-520{ }^{\circ} \mathrm{C}$ (Cardaci, 1987).

\section{Summary and discussion}

The RSCM data presented in this study allowed us to better constrain the relationships between the nappe architecture and the thermal structure in the Alpi Apuane and their surroundings. This highlighting new subjects for a better and more complete understanding of the thermo-mechanical evolution and exhumation history of the inner Northern Apennines in the general frame of the evolution of the Apennines orogen. Hereafter the results and the first order points of our contribution are summarized and discussed. 
413 A first point to be remarked is the difference in the mean peak $\mathrm{T}$ among the 414 structurally/stratigraphically defined tectonic units (Fig. 7). The classically accepted subdivision 415 (Elter, 1975, Carmignani and Kligfield, 1990; Decandia et al., 1996, Vai and Martini, 2001) into 416 three major continental units forming the backbone of the inner Northern Apennines - from top to 417 bottom: the Tuscan nappe, the Massa and the Apuane units - appears to be fully supported by the new measured RSCM T (Fig.7) which show a mean peak T of $\sim 260{ }^{\circ} \mathrm{C}$ for the Tuscan Nappe, $419485{ }^{\circ} \mathrm{C}$ for the Massa unit and $\sim 385{ }^{\circ} \mathrm{C}$ for the Apuane unit.

420 Moreover, our data allow defining new tectonic units that were not clearly identified and considered 421 in the previous models. In such group of units may be included the Punta Bianca Unit in the west 422 and the Monte Pisano Unit in the south. Moreover, in the southern-eastern Alpi Apuane the Panie 423 may be inserted within this group, since they are here characterized by a RSCM T of $320{ }^{\circ} \mathrm{C}$, an 424 intermediate value between those of the Apuane Unit and those of the Tuscan Nappe. Other 425 evidence of missing units, inside the Alpi Apuane, may be searched for between the Massa unit and 426 the overlying Tuscan Nappe (Fig.5 cross section E), where remnants of a post mid-Triassic cover 427 (cherty metalimestones, marbles, phyllites) with a peak RSCM T of $\sim 350{ }^{\circ} \mathrm{C}$ were sampled (sample 428 16). Those remnants are also observable as structural relicts exposed as hectometer to 429 pluridecameter thick slices and lenses (see Molli et al., 2000) and widely recognizable as clasts 430 (meter, decimeter to centimeter in scale) within the carbonate tectonic breccia at the base of the 431 Tuscan Nappe in the southern Alpi Apuane (Conti et al., 2009; CARG F.260; Cinquini and Molli, 432 2015). These data and occurences may be interpreted as related to the former existence of a 433 metasedimentary unit ("X unit", "missing section" in Fellin et al. 2007) originally including the 434 post Mid-Triassic cover sequence now only scatterly observable on top of the Massa Unit.

435 The rank of individual tectonic unit for the Panie (Maxwell, 1956; Nardi, 1961; Giglia 1967; 436 Carmignani et al., 2001) as well as the importance of the "X unit" to fill the gap between the base of 437 the Tuscan Nappe and the top of the Massa unit during the syn-peak metamorphism nappe stacking 438 are in line with what anticipated and discussed in the frame of the tectonic history of the 439 metamorphic units by Molli et al., (2000); Molli et al., (2002); Fellin et al. (2007). Thanks to the 440 newly defined RSCM data, and considering the mean T as an estimate for the "whole unit" thermal 441 peak, we may emphasize that the classical subdivision into three major Tuscan units across the Alpi 442 Apuane and surrounding introduced in literature since Elter (1975) as related to the original thrust 443 stacking, is due instead to tectonic excision during exhumation. In other words, the present day 444 tectonic units have to be considered as remnants of a former thicker, more complete and now only 445 partially preserved contractional nappe stack (Coli, 1989; Van den Berg, 1989; Carmignani et al., 
1990; Carmignani et al. 1995; Jolivet et al., 1998; Molli et al., 2002).

\subsection{Metamorphic field gradients and thermal architecture}

For the Tuscan Nappe, the dataset in the La Spezia area (Fig.2, 6) indicates a base (Triassic

Rhaetian limestone) to top (Oligocene-early Miocene Macigno sandstone) difference of $\sim 40{ }^{\circ} \mathrm{C}$ which occurs within a structural distance of $2000 \mathrm{~m}$. Thus, assuming that the peak T are: (i) coheval in age and (ii) related with the pre-folding thermal architecture of the unit within the orogenic prism, a peak T normal-type field gradient of $20^{\circ} \mathrm{C} / \mathrm{Km}$ may be defined (Fig. 10).

At regional scale, the collected data from the Tuscan Nappe suggest for its westernmost exposure (La Spezia area) a mean RSCM T of $271^{\circ} \mathrm{C}$ and a lower mean $\mathrm{T}$ of $227^{\circ} \mathrm{C}$ in the easternmost position in the Lima Valley, east of the Alpi Apuane (Fig.1,2,10). This west to east decrease of peak $\mathrm{T}$, in line with previously recorded illite crystallinite and organic matter data (Reutter et al., 1978, 1983; Cerrina Feroni et al., 1983), may be referred to an original thickness of the orogenic wedge stack above the Tuscan Nappe. Moreover, assuming that the field gradient defined in the La Spezia area was constant at regional scale, this results in a variation of the wedge thickness above the Tuscan Nappe of $2 \mathrm{Km}$ from west (La Spezia) to east (Val di Lima) (Fig.10).

For the Alpi Apuane, taking into account the whole data set in the Apuane unit, a difference in $\mathrm{T}$ between the pre-Mesozoic samples and the Mesozoic to Tertiary ones may be underlined (Figs. 4, $5,8,9)$. The pre-Mesozoic basement rocks show a mean peak RSCM T of $445{ }^{\circ} \mathrm{C}$ whereas a mean of $386^{\circ} \mathrm{C}$ is found in the metasedimentary Mesozoic to Tertiary cover.

These data may be explained considering the higher peak $\mathrm{T}$ in the basement rock as a relict metamorphism of the Variscan age (Conti et al., 1993, Pandeli et al., 2003) or as a relict of a Late Variscan (Permian) thermal event in line with recently acquired data (Vezzoni et al., 2017; Pieruccioni et al., 2017).

Nevertheless, since similar higher T (Fig.8) were also found in samples with Mesozoic to Tertiary protoliths, an alternative hypothesis may also be taken into account. In this alternative frame, an Apenninic-age heating possibly related to a fluid flow infiltration in the basement rocks (and locally in the Mesozoic cover) during its detachment from the underlying subducted middle to lower crust may be envisaged (Fig. 10d). The higher peak T found in association with mineralized horizons in the southern Alpi Apuane ("Zona dello Stazzemese” or "Stazzemese Shear Zone” Figs. 9, 10) may thus be interpreted as an evidence of Apenninic-age infiltration and hot fluid flow along high-strain 
Finally, the distribution of peak $\mathrm{T}$ at the scale of the whole Alpi Apuane (Fig.9) indicates a different and systematic arrangement with respect to the overall architecture of the structures in the northwest as opposed to the south-easternmost part. The north-west part of the Alpi Apuane (Figs. 5,9) is characterized by a SW to NE decrease of peak temperature from $495{ }^{\circ} \mathrm{C}$ in the west to $357{ }^{\circ} \mathrm{C}$ in the central and $336^{\circ} \mathrm{C}$ in the eastermost position. A difference of $125^{\circ} \mathrm{C}$ is observed with a structural distance of $\sim 8 \mathrm{Km}$, thus an inverted field metamorphism with a $\mathrm{T}$ gradient of $\sim 20 \% \mathrm{Km}$ could be defined.

Furthermore, the distribution of the peak temperatures and the resulting thermal architecture are different in the south-east part of the Alpi Apuane (Fig. 9) where an apparent normal-type gradient is observed with transition from temperatures higher than $500{ }^{\circ} \mathrm{C}$ to less than $300{ }^{\circ} \mathrm{C}$ (projected base of the Tuscan Nappe) in less than 1,5 Km (e.g. cross-section L) with an apparent field gradient in excess of $90^{\circ} \mathrm{C} / \mathrm{Km}$.

This clearly points out the complexity of the thermal vs. structural architecture in the Alpi Apuane which well fits an overall "contractional" model of antiformal stacking (i.e. an orogenic wedge dominated by material advenction) in the northern part and an opposite "extensional" core complex model with condensed isograds (i.e. an orogenic wedge dominated by temperature advenction) for its southernmost part.

This variability in the thermal structure between the two sectors of the Alpi Apuane, however, may be only apparent since the exposed geometrically deepest and cooler levels of the eastern Alpi Apuane are not exposed in the central-southeasternmost segment of the dome in relationship with its 3D structure, see below (Fig.9).

\subsection{Regional structures of the Alpi Apuane, kinematic and paleothermal evolution}

\subsubsection{Internal deformation of the Alpi Apuane metamorphic core}

The regional structure of the Alpi Apuane metamorphic core is that of an asymmetric antiform dome-like structure defined by the attitude of the main foliation D1 dipping west along the western side of the dome and to the east along the eastern side (Carmignani and Giglia, 1979; Kligfield et al., 1979; Kligfield et al., 1981; Carmignani and Kligfield, 1990; Carmignani et al., 1995; Molli and Vaselli, 2007; Molli and Meccheri, 2012). This regional scale antiform (Figs. 4,5,9) shows internal complexities due to the presence of two minor culminations, respectively centered in the south west and north east part of the dome (Figs. 4,9). The paleoisotherms defined by our RSCM data are deformed by the later (i.e. post-D1) dome-shaped regional structures of the core, resulting in an apparently inverted type field gradient in the north-west, where the main phase (D1) isoclinal 
514 regional fold structures (Bergiola Anticline in the Massa unit, Carrara Syncline, Vinca-Forno anticline and Orto di Donna syncline, Figs. 4,5) and related axial planar folition D1 are westdipping, and in a normal type field gradient in the east and southeast part of the Alpi Apuane, where the main phase (D1) isoclinal regional fold structures, e.g. the M.Corchia syncline (southern prolongation of the Orto di Donna-Altissimo syncline), and related axial planar foliation D1 are east- or south/east-dipping.

These relationships betwen the paleothermal architecture and regional deformation features within the Alpi Apuane and surroundings area may be inserted in the conceptual model suggested in Figure 10, which takes into account all available structural and geo-thermochronological data together with presented RSCM results.

524 The proposed evolutionary model envisages: i) crustal underplating of the Tuscan continental units

525 (Fig. 10a,b) with an early stage of underthrusting and stacking below the Ligurian/subligurian lid 526 (former Ligurian Tethys-derived accretionary wedge). Assuming a constant thermal gradient of 20 ${ }^{\circ} \mathrm{C} / \mathrm{Km}$ as defined in the upper continental unit (Tuscan Nappe), a $\mathrm{T}>400{ }^{\circ} \mathrm{C}$ was reached at crustal depth major than $20 \mathrm{Km}$, thus fitting available petrological data (Franceschelli et al., 1986; Molli et al, 2000) and our RSCM data. The Massa unit, originally derived from the westernmost position, records higher T (and P) peaks, with respect to the Apuane unit (see also Jolivet et al., 1998; Molli et al., 2000a,b); ii) a successive duplexing stage (Fig. 10c,d) may be responsible for the formation of the internal stacking and regional fold development including the overthrusting of the Massa (higher grade) unit above the Apuane unit (lower grade). During this deformation stage (late D1 in Molli et al., 2000), and following the thermo-kinematic model proposed by Dunlop et al. (1997) and Bollinger et al. (2004) a folding of previous paleoisotherms is suggested to produce the paleothermal and structural features in the western side of the Alpi Apuane across the contact between the Massa and the Apuane units and downward (Figs. 4,5).

538 During the crustal duplexing and antiformal stacking (Fig. 10d,e,f) a possible pathway for hot fluids coming from middle to lower crust may be suggested along some major tectonic contact and along the decollement level at the base of detached Paleozoic terms. This hot fluid channelling associated with ore mineralization was localized with the ongoing deformation and after the refolding of previous D1 structures in the eastern limb of the regional antiformal stack within the "Stazzemese 543 Shear Zone" (Figs. 9,10e,f).

544 The successive stages of deformation in the Alpi Apuane metamorphic core recorded the switching in the deformation mode from crustal thickening to crustal thinning in the wake of eastward 546 migration of contraction/extensional fronts which characterize the Northern Apennines 547 development (Elter et al., 1975; Patacca et al., 1990; Carmignani, Kligfield, 1990; Carmignani et 
al., 1995; Doglioni, 1991; Pialli et al., 1998; Liotta and Ranalli, 1999; Le Breton et al., 2017 and references therein). During the vertical shortening of the previously developed antiformal stack the "Stazzemese Shear Zone" as well as the later flat lying regional D2 foliation and structures were formed (Fig.10g, h).

\subsubsection{The Alpi Apuane metamorphic core and its boundary faults}

As previously illustrated, the Alpi Apuane metamorphic core forms a regional scale northwestsoutheast trending elliptical dome, which is separated by the overlying Tuscan Nappe by meter to hundreds of meters thick levels of carbonatic breccias and cataclasites which have been considered since Trevisan (1965) as derived from the former basal layer of the Tuscan Nappe, i.e. by an original alternation of dolomites and evaporites of Triassic age ("Calcare Cavernoso" Auct.). Carmignani and Kligfield (1990) first interpreted this breccia-layer ("window fault" in Hodgkins and Stewart, 1994; Casale, 2012) as the detachment horizon that separates low-grade to unmetamorphic upper-plate units (our RSCM T $<300^{\circ} \mathrm{C}$ ) from the underlying metamorphic lower plate units $\left(401 \pm 65^{\circ} \mathrm{C}\right.$ mean of all our data set of RSCM T).

From the kinematic point of view the "window fault" cuts down-section the footwall regional structures along a south-west to north-east transport direction (Molli, 2012) as shown in map and cross section in Figs. 4,5,9. The low angle detachment fault is therefore in contact with the uppermost structures of the western Alpi Apuane (Massa unit, Carrara Syncline, Vinca-Forno Anticline) and with progressively deeper and lower regional structures (Orto di Donna Syncline, Tambura Anticline and easternmost Apuane).

569 This structural cut-down section corresponds to a paleothermal architecture which shows, across the "window fault" and along the transport direction, an eastward decrease in the $\mathrm{T}$ gap between hangingwall and footwall from $\Delta \mathrm{T}>200{ }^{\circ} \mathrm{C}$ in the west to $\Delta \mathrm{T}<50{ }^{\circ} \mathrm{C}$ in the east (Fig.9). This is mainly due to the cross-cut relationship and kinematic interaction between the window fault and the footwall antiformal stack of the metamorphic core as figured in the conceptual model of Figure 10e,h. Note that the window fault mainly formed by breccias and cataclasites derived from the basal layers of the Tuscan Nappe locally includes (for instance in the southern Alpi Apuane) crushed and brittely deformed relicts of X/“missing unit" originally on top of the Massa and Apuane units. Furthermore, using the thermochronological data in Fellin et al. (2007), we may date some steps of the proposed kinematic history with the end of distributed deformation in the footwall metamorphic core, the antiformal stack development and the later Stazzemese Shear zone and D2 folding as occured before $11 \mathrm{Ma}$, a time at which the Alpi Apuane metamorphic core reached a temperature of c. $250^{\circ} \mathrm{C}$ as constrained by Zr FT age (Fellin et al., 2007). Localized brittle deformation along low 
angle normal faults and the end of the activity of the "window fault" occurred at a crustal depth as low as $\sim 180^{\circ} \mathrm{C}$ in a time interval between 7 to $4-5 \mathrm{Ma}$ based on data collected along the western and in the eastern side of the Alpi Apuane by Fellin et al. (2007). After that time crustal extension was accommodated by the high angle (mainly) normal faults which shaped the present day tectonic setting, the regional morphostructure and the deep crustal structure (Fig., 4,5,9, 10i,1). The high angle faults cross-cut the former synmetamophic structures as well as the "window fault" (Molli et al., 2016 and references therein).

\section{Conclusions}

RSCM T estimates have proven an efficient mean to put extensive $\mathrm{T}$ constraints on the thermal structure of coherent units and on tectonic contacts even within very narrow $\mathrm{T}$ ranges (Beyssac et al., 2002; Rahl et al., 2005; Chen et al., 2011; Vitale Brovarone et al., 2013, 2014; Bellanger et al., 2014; Scharf et al., 2013; Wiederkehr et al., 2011).

596 Our data in the Alpi Apuane metamorphic core well illustrate how RSCM T distribution are related/controlled in different ways by regional and local deformation structures and in turn that the observed style of deformation and type of structures are controlled/related with local paleotemperatures.

600 Since the seminal paper of Carmignani and Kligfield (1990), the Alpi Apuane have been worldwide recognized as a metamorphic core complex (Withney et al., 2013), recording mid-crustal distributed post-orogenic "ductile" extensional deformation. This view, however, has been questioned by different authors who have suggested that extensional denudation of the Alpi Apuane was instead related with underplating and thickening of the internal Northern Apennines (among others Cello and Mazzoli, 1996; Jolivet et al., 1998, Fellin et al., 2007).

606 Beside localized fluid-mediated thermal effects (see Section 4), our RSCM data document that the paleothermal architecture of the Alpi Apuane metamorphic core better fits a tectonic scenario of syn-orogenic contractional exhumation associated with a cool paleothermal gradient, which allowed the preservation of inverted metamorphism across the Alpi Apuane metamorphic core and its overall paleothermal architecture.

611 Nevertheless, post-antiformal stack structures (regional flat-lying D2 foliation and the Stazzemese 612 Shear zone) may be related to the switching and transition from crustal thickening to crustal 613 thinning, when the metamorphic core was already at mid crustal depth (c.15 Km and temperature of $614 \leq 350^{\circ} \mathrm{C}$ ). Our major conclusions put new contraints for the thermo-mechanical evolution and 615 exhumation history of the Northern Apennine in its inner (western) side; moreover, they may be of 
general and widespread interest for other orogens, showing anchimetamorphic to metamorphic mid

617 to shallow crustal terrains and metamorphic cores. Our data clearly illustrate how the thermal and 618 metamorphic signature may have different characters and different field gradients at tens of 619 kilometer scale, calling for a careful analysis of thermal data in correlation with the associated 620 structural architecture for a firm interpretation of the tectonic frame at the orogen-scale.

\section{Acknowledgements}

624

625 All the data used for this paper are listed in the references. This work was supported by the Pisa 626 University, Ateneo funds. IC was awarded an Erasmus Placement grants for her staying at the IRD, 627 Institut de Minéralogie, de Physique des Matériaux et de Cosmochimie, IMPMC, Paris.

628 David Iacopini, an anonymous reviewer and the editors of Special Issue are acknowledged for their 629 helpful comments and suggestions which improved our paper.

630 GM wants to thanks Eline Le Breton, Martina Zucchi, Andrea Brogi, Mark Handy, Domenico 631 Liotta, Giorgio Minelli and Kamil Ustaszewski for the discussions about contents of this paper 632 during a 2016 Field trip in Tuscany as well as during invited talks held in Berlin, Bari and Jena. 633 This paper is dedicated to the memory of Marco Meccheri. 


\section{References}

Allemand, P., Lardeaux, J.-M., 1997. Strain partitioning and metamorphism in a deformable orogenic wedge: application to Alpine belt. Tectonophysics 280, 157-169.

Agard, P., Vitale Brovarone, A., 2013. Thermal regime of continental subduction: the record from exhumed HP-LT terranes (Oman, N. Caledonia, Corsica). Tectonophysics, 602, 206215, DOI:10.1016/j.tecto.2013.05.011

Aygüll, M., Okay, A.I., Oberhänsli, R., Ziemann, M.A., 2015. Thermal structure of low-grade accreted Lower Cretaceous distal turbidites, the Central Pontides, Turkey: insights for tectonic thickening of an accretionary wedge. Turkish J Earth Sci 24, 461-474

Baldacci F., Elter P., Giannini E., Giglia G., Lazzarotto A., Nardi R., Tongiorgi M., 1967. Nuove osservazioni sul problema della Falda Toscana e sull'interpretazione dei flysch arenacei tipo "Macigno" nell'Appennino Settentrionale. Memorie Società Geologica Italiana 6, 199-211.

Balestrieri, M.L., Bernet, M., Brandon, M.T., Picotti, V., Reiners, P., Zattin, M., 2003. Pliocene and Pleistocene exhumation and uplift of two key areas of the Northern Apennines. Quaternary International 101/102, 67-73.

Balestrieri, M.L., Pandeli, E., Bigazzi, G., Carosi, R., Montomoli, C. 2011. Age and temperature constraints on metamorphism and exhumation of the syn-orogenic metamorphic complexes of Northern Apennines, Italy. Tectonophysics 509, 254-271

Barchi M.R., Minelli G., Pialli G., 1998. The CROP03 profile: a synthesis of results on deep

Beyssac, O., Goffé, B., Chopin, C., Rouzaud, J.N., 2002a. Raman spectra of carbonaceous material 679 in metasediments: a new geothermometer. Journal of Metamorphic Geology 20, 859-871. pressure, low-temperature graphitization: a Raman microspectroscopy and HRTEM study. 
685 Beyssac, O., Goffé, B., Petitet, J.P., Froigneux, E., Moreau, M., Rouzaud, J.N., 2003. On the characterization of disordered and heterogeneous carbonaceous materials using Raman spectroscopy. Spectrochimica Acta 59, 2267-2276.

Beyssac, O., Bollinger, L., Avouac, J.P., Goffé, B., 2004. Thermal metamorphism in the lesser

Himalaya of Nepal determined from Raman spectroscopy of carbonaceous material. Earth and Planetary Science Letters 225, 233-241.

Beyssac, O., Simoes, M., Avouac, J.P., Farley, K.A., Chen, Y.G., Chan, Y.C., Goffe', B., 2007. 10.1029/2006TC002064.

Berger, A., Schmid, S.M., Engi, M., Bousquet, R., Wiederkehr, M., 2011. Mechanisms of mass and heat transport during Barrovian metamorphism: A discussion based on field evidence from the Central Alps (Switzerland/northern Italy), Tectonics 30, TC1007, doi:10.1029/2009TC002622,

Bernoulli, D., 2001. Mesozoic-Tertiary Carbonate Platforms, Slopes and Basins of the external Apeninnes and Sicily. In: Vai, G.B. and Martini, I. P. (eds) Anatomy of an Orogen. Kluwer Academic Publishers, 307-326.

Bernoulli, D., Kälin, O., Patacca, E., 1979. A Sunken Continental Margin of theMesozoic Tethys: the Northern and Central Apennines. Ass. Sedimen. Franç. Publ.Sp., 1, pp. 197-210.

Biagioni, C., D’Orazio, M., Vezzoni, S., Dini, A., Orlandi, P., 2013. Mobilization of Tl-Hg-As-Sb$(\mathrm{Ag}, \mathrm{Cu})-\mathrm{Pb}$ sulfosalt melts during low-grade metamorphism in the Alpi Apuane (Tuscany, Italy) Geology 41 (7), 747-750, doi.org/10.1130/G34211.1.

Biagioni, C., Dini, A., Orlandi, P., Moëlo, Y., Pasero, M., Zaccarini, F., 2016. Lead-Antimony 713 Sulfosalts from Tuscany (Italy). XX. Members of the Jordanite-Geocronite Series from the Pollone 714 Mine, Valdicastello Carducci: Occurrence and Crystal Structures. Minerals, 6, 715 doi:10.3390/min6010015.

717 Boccaletti, M., Bonini, M., Moratti, G., Sani, F., 1999. Compressive Neogene-Quaternary tectonics 
718 in the hinterland area of the Northern Apennines. In: Boccaletti, M., Dahmani, M., Bonini Moratti, 719 G. (Eds.), Neogene Sedimentation and Tectonics in the Western Mediterranean. Journal of Petroleum Geology, 22, pp.37-60.

Bonini, M., Sani, F., 2002. Extension and compression in the northern Apennines (Italy) hinterland: evidence from the late Miocene-Pliocene Siena-Radicofani Basin and relations with basement structures. Tectonics 22, 1-35.

Bortolotti, V., Principi, G., Treves, B., 2001. Ophiolites, Ligurides and the tectonic evolution from spreading to convergence of a Mesozoic Western Tethys segment. In: Vai, G.B. and Martini, I.P. (eds) Anatomy of an Orogen. Kluwer Academic Publishers, 327-350.

Botti F., Aldega L., Corrado S., 2004. Sedimentary and tectonic burial evolution of the Northern Apennines in the Modena-Bologna area: constraints from combined stratigraphic, structural, organic matter and clay mineral data of Neogene thrust-top basins. Geodinamica Acta 17, 185-203.

Bousquet, R., Oberhänsli, R., Schmid, S.M., Berger, A., Wiederkehr, M., Robert, C., Möller, A., CCGM/CGMW, http://www.geodynalps.org

Brogi, A., Liotta, D., 2008. Highly extended terrains, lateral segmentation of the substratum, and basin development: the middle-Late Miocene Radicondoli Basin (inner Northern Apennines, Italy). Tectonics 27, TC5002. doi:10.1029/2007/TC002188.

Brown, M., 2008. Characteristic thermal regimes of plate tectonics and their metamorphic imprint throughout Earth history: when did Earth first adopt a plate tectonics mode of behavior? In: Condie, K., Pease, V. (Eds.), When did Plate Tectonics Begin? Geological Society of America Special

Brown, M., 2009 Metamorphic patterns in orogenic systems and the geological record. In Cawood, P. A. \& Kroner, A. (eds) Earth Accretionary Systems in Space and Time. The Geological Society, London, Special Metamorphic patterns in orogenic systems and the geological record Publications, 
Alpine-Apennine perspective. Journal of Structural Geology 28, 1893-1908 doi.org/10.1016/j.jsg.2006.09.006

Caricchi, C., Aldega, L., Corrado, S., 2014. Reconstruction of maximum burial along the Northern Apennines thrust wedge (Italy) by indicators of thermal exposure and modelling. Geological Society of America Bulletin doi: 10.1130/B30947.1.9

Carlini, M., Artoni, A., Aldega, L., Balestrieri, M.L., Corrado, S., Vescovi, P., Bernini, M., Torelli, L., 2013, Exhumation and reshaping of far-travelled/allochthonous tectonic units in mountain belts. New insights for the relationships between shortening and coeval extension in the western Northern Apennines (Italy) Tectonophysics, 608, 267-287, doi:10.1016/j.tecto 2013.09.029.

Carminati, E., Doglioni, C., 2012. Alps vs. Apennines: The paradigm of a tectonically asymmetric Earth. Earth-Science Reviews 112, 67-96, doi:10.1016/j.earscirev.2012.02.004

Carmignani, L. , Giglia, G., 1979. Large scale reverse "drag folds" in the late Alpine building of the Apuane Alps (N. Apennines). Atti della Societa Toscana di Scienze Naturali, Memorie, Serie A 86, 109-126.

Carmignani, L., Kligfield, R., 1990. Crustal extension in the Northern Apennines: the transition from compression to extension in the Alpi Apuane Core Complex. Tectonics 9, 1275-1303.

Carmignani, L., Giglia, G., Kligfield, R., 1978. Structural evolution of the Apuane Alps: an example of continental margin deformation in the Northern Apennine. Journal of Geology 86, 487504.

Carmignani, L., Decandia, F.A., Fantozzi, P.L., Lazzarotto, A., Liotta, D., Meccheri, M., 1994. Tertiary extensional tectonics in Tuscany (Northern Apennines, Italy). Tectonophysics 238, 295315.

Carmignani, L., Decandia, F.A., Disperati, L., Fantozzi, P.L., Kligfield, R., Lazzarotto, A., Liotta, D., Meccheri, M., 2001. Inner Northern Apennines, in: Vai, G.B., and Martini, I.P. (eds.), Anatomy of an Orogen: the Apennines and Adjacent Mediderranean Basins, 197-214. 
Carosi R., Leoni L., Tamponi M., 1993. Temperature del metamorfismo nell'Unità di S. Maria del 788 Giudice (Monti Pisani, Appennino Settentrionale). Atti della Societa Toscana di Scienze Naturali, Memorie, Serie A, 99, 161-173.

Carosi, R., Leoni, L., Montomoli, C., Sartori, F., 2003. Very low-grade metamorphism in the Tuscan Nappe, Northern Apennines, Italy: relationships between deformation and metamorphic indicators in the La Spezia mega-fold. Schweizerische Mineralogische und Petrographische

Carosi, R., Montomoli, C., Pertusati, P.C., 2004. Late tectonic evolution of the Northern Apennines: the role of contractional tectonics in the exhumation of Tuscan units. Geodinamica Acta 17, 253273.

Carter, K.E., Dworkin, S.I., 1990. Channelized fluid flow through shear zones during fluid-assisted dynamic recrystallization, Northern Appenines, Italy. Geology 15, 720-723.

Casale, G., 2012. Core complex exhumation in peri-Adriatic extension, and kinematics of Neogene slip along the Saddle Mountains thrust, Ph.D Thesis, University of Washington, 85 pp.

Cerrina Feroni, A.G., Plesi, G., Fanelli, G., Leoni, L., Martinelli, P., 1983. Contributo alla conoscenza dei processi metamorfici di grado molto basso (anchi-metamorfismo) a carico della

Chen C-T., Chang Y-C, Lu C-L., Simoes, M., Beyssac, O., 2011. Nappe structure revealed by thermal constraints in the Taiwan metamorphic belt Terra Nova 23, 85-91, doi: 10.1111/j.13653121.2011.00987.x

Ciarapica, G., Passeri, L., 2002. The palaeogeographic duplicity of the Apennines. Bollettino

Cinquini, I., 2014. Termometria RSCM nelle Alpi Apuane: nuovi vincoli sull'evoluzione tettonometamorfica dell’Appennino interno. Tesi di Laurea Università di Pisa, 80 pp. 
823 Clemenzi, L., Molli, G., Storti, F., Muchez, P., Swennen, R., Torelli, L., 2014. Extensional 824 deformation structures within a convergent orogen: The Val di Lima low-angle normal fault system 825 (Northern Apennines, Italy). Journal of Structural Geology 66, 205-222.

827 Clemenzi L., Storti F., Balsamo F., Molli G., Ellam R., Muchez P., Swennen R., 2015. Fluid 828 pressure cycles, variations in permeability, and weakening mechanisms along low-angle normal 829 faults: The Tellaro detachment, Italy. Geological Society of America Bulletin, doi:10.1130/B31203.1

Conti, P., Gattiglio, M., Meccheri, M., 1991. The overprint of the Alpine tectonometamorphic evolution on the Hercynian orogen: an example from the Apuane Alps (Northern Apennines, Italy). Tectonophysics 191, 335-346.

Conti, P., Di Pisa, A., Gattiglio, M., Meccheri, M., 1993. Prealpine basement in the Alpi Apuane (Northern Apennines, Italy). In: Von Raumer, J.F., Neubauer, F. (Eds.), Pre-Mesozoic geology in the Alps. Springer Verlag, pp. 609-621. Note illustrative Carta geologica d'Italia alla scala 1:50.000. Foglio 260 Viareggio, ISPRA.

Consani, V. 2003 Geologia dell'area compresa tra Foce di Mosceta e Cardoso (Alpi Apuane Meridionali) Tesi di Laurea Università di Pisa, 119 pp.

Cortecci, G., and Orlandi, P., 1975. Oxygen- and carbon-isotopic composition of gypsum-calcitedolomite crystals and metamorphic marble assemblages: Chemical Geology, v. 15, p. 309-314, doi:10.1016/0009-2541(75)90041-8.

Cortecci, G., Leone, G., and Pochini, A., 1994. Stable isotope composition and geothermometry of metamorphic rocks from the Apuane Alps, northern Tuscany, Italy: Mineralogica et Petrographica Acta, v. 37, p. 51-62.

Costagliola, P., Benvenuti, M., Lattanzi, P., and Tanelli, G., 1998, Metamorphic barite-pyrite (Pb855 
inclusions and geochemistry: Mineralogy and Petrology 62, 29-60, doi:10.1007/BF01173761.

Corti, G., Serena, L., Bonini, M., Sani, F., Mazzarini, F., 2006. Interaction between normal faults and pre-existing thrust systems in analogue models. In: Buiter, S.J.H., Schreurs, G. (Eds.), Analogue and numerical modeling of crustal-scale processes: Geol. Soc. Lond. Spec. Publ., 253, pp. $65-78$.

Cottle, J.M., Waters, D.J., Riley, D., Beyssac, O., Jessup, J., 2011. Metamorphic history of the South Tibetan Detachment System, Mt. Everest region, revealed by RSCM thermometry and phase equilibria modelling. Journal metamorphic Geology, 2011, 29, 561-582. doi:10.1111/j.15251314.2011.00930.x

Cuffaro, M., Riguzzi, F., Scrocca, D., Antonioli, F., Carminati, E., Livani, M., Doglioni, C., 2010. On the geodynamics of the northern Adriatic plate. Rendiconti Fisiche Accademia di Lincei 21 (Suppl. 1), S253-S279. http://dx.doi.org/10.1007/s12210-010-0098-9.

Della Vedova, B., Bellani, S., Pellis, G., Squarci, P., 2001 Deep temperatures and surface heat flow distributions. In: Vai, G.B. and Martini, I. P. (eds) Anatomy of an Orogen. Kluwer Academic Publishers, 65-76.

Dellisanti, F., Pini, G.A., Baudin, F., 2010. Use of Tmax as a thermal maturity indicator in orogenic

Dini, A., Benvenuti, M., Costagliola, P., Lattanzi, P., 2001. Mercury deposits in metamorphic settings: the example of Levigliani and Ripa mines, Apuane Alps (Tuscany, Italy). Ore Geology Review 18, 149-167.

882

Di Pisa, A., Franceschelli, M., Leoni, L., Meccheri, M., 1985. Regional variation of the metamorphic temperatures across the Tuscanid 1 Unit and its implications on the alpine metamorphism (Apuan Alps, N-Tuscany). Neues Jahrbuch fuer Mineralogie, Abhandlungen 151,

Di Stefano, R., Kissling, E., Chiarabba, C., Amato, A. \& Giardini, D., 2009. Shallow subduction 889 
based on highquality P wave arrival times, Journal of Geophysical Research-Solid Earth 114, B05305, doi:10.1029/2008JB005641.

Doglioni, C., Mongelli, F., Pialli, G., 1998. Boudinage of the Alpine belt in the Apenninic back-arc. Memorie Società Geologica Italiana 52, 457-468.

Ellero, A., Leoni, L., Marroni, M., \& Sartori, F., 2001. Internal Liguride Units from Central Liguria, Italy: new constraints to the tectonic setting from white mica and chlorite studies. Schweizerische Mineralogische und Petrographische Mitteilungen 81, 39-53.

Elter, P., 1975. Introduction à la géologie de l'Apennin septentrional. Bulletin de la Societé Geologique de France 7, 956-962.

Elter, P., Giglia, G., Tongiorgi, M., and Trevisan, L., 1975. Tensional and compressional areas in the recent (Tortonian to present) evolution of the Northern Apennines: Bollettino di Geofisica Teorica ed Applicata 17, 3-18.

Eva, E., Solarino, S., Boncio, P., 2014. HypoDD relocated seismicity in northern Apennines (Italy) preceding the 2013 seismic unrest: seismotectonic implications for the Lunigiana-Garfagnana area. Bollettino Geofisica Teorica ed Applicata 55, 739-754.

Faccenda, M., Minelli, G., Gerya, T.V., 2009. Coupled and decoupled regimes of continental collision: Numerical modeling. Earth and Planetary Science Letters 278, 337-349 doi:10.1016/j.epsl.2008.12.021

Faccenna, C., Becker, T.W., Miller, M.S., Serpelloni, E., Willet, S., 2014. Isostasy, dyanmic topography, and the elevation of the Apennines of Italy. Earth and Planetary Science Letters 407, $163-174$.

Fazzuoli M., Pandeli E., Sani F., 1994. Considerations on the sedimentary and structural evolution of the Tuscan Domain since early Liassic to Tortonian. Memorie Società Geologica Italiana, 48, 3150.

Fellin, M.G., Reiners, P.W., Brandon, M.T., Wuthrich, E., Balestrieri, M.L., 2007. 
924 Thermochronologic evidence for exhumational history of the Alpi Apuane metamorphic core 925 complex, northern Apennines, Italy. Tectonics 26, TC6015.

927 Franceschelli M., Memmi I., 1999. Zoning of chloritoid from kyanite-facies metapsammites, Alpi 928 Apuane, Italy. Mineralogical Magazine, 63, 105-110.

930 Franceschelli M., Leoni L., Memmi I., Puxeddu M., 1986. Regional distribution of Al-silicates and 931 metamorphic zonation in the low-grade Verrucano metasediments from the Northern Apennines, 932 Italy. Journal Metamorphic Geology, 4, 309-321.

Franceschelli M., Memmi I., Carangiu G., Gianelli G., 1997. Prograde and retrograde chloritoid zoning in low temperature metamorphism, Alpi Apuane, Italy. Schweizerische Mineralogische und Petrographische Mitteilungen 77, 41-50.

Gabalda, S., Beyssac, O., Jolivet, L., Agard, P., Chopin, C., 2008. Thermal structure of a fossil subduction wedge in the Western Alps. Terra Nova, 21, 28-34.

Gandin A., Guasparri G., Mugnaini S., Sabatini G., 2000. The Calcare Cavernoso of the Montagnola Senese (Siena, Italy): mineralogical-petrographic and petrogenetic features. Miner. Petrogr. Acta, 43, 271-289.

Gattiglio, M., Meccheri, M., Tongiorgi, M., 1989. Stratigraphic correlation forms of the Tuscan Palaeozoic basement. Rendiconti della Società Geologica Italiana 12, 247-257.

Gianmarino, S., Giglia, G., 1990. Gli elementi strutturali della piega di La Spezia nel contesto geodinamico dell’Appennino Settentrionale. Bollettino Società Geologica Italiana 109, 683-692.

Giglia, G., 1967. Geologia dell'Alta Versilia settentrionale (Tav. M.Altissimo). Memorie della Societa Geologica Italiana 6, 67-95.

954 Giglia G, Radicati di Brozolo F., 1970. K/Ar age of metamorphism in the Apuane Alps (Northern 955 Tuscany). Bollettino Società Geologica Italiana 89, 485-497. 
the Swiss Alps. Tectonophysics, 404, 55-76.

Hodgkins M.A. \& Stewart K.G., 1994. The use of fluid inclusions to constrain fault zone pressure, temperature and kinematic history: an example from the Alpi Apuane, Italy. Journal of Structural Geology, 16, 85-96.

Jolivet, L., Faccenna, C., Goffé, B., Mattei, M., Rossetti, F., Brunet, C., Storti, F., Funiciello, R., Cadet, J.P., D’Agostino, N., Parra, T., 1998. Midcrustal shear zones in postorogenic extension: example from the northern Tyrrhenian Sea. Journal of Geophysical Research, 103, 12123-12160.

Kligfield, R., 1979. The Northern Apennine as a collisional orogen. American Journal of Science 969 $279,679-681$.

Kligfield, R., Carmignani, L., Owens, W. H., 1981. Strain analysis of a Northern Apennine shear zone using deformed marble breccias. Journal of Structural Geology, 3, 421-436.

Kligfield, R., Hunziker, J., Dallmeyer, R.D., Schamel, S., 1986. Dating of deformational phases using K-Ar and 40Ar/39Ar techniques: results from the Northern Apennines. Journal of Structural Geology 8, 781-798.

Lahfid, A., Beyssac, O., Deville, E. Negro, F. Chopin, C. Goffe', B., 2010 Evolution of the Raman spectrum of carbonaceous material in low-grade metasediments of the Glarus Alps (Switzerland). Terra Nova, 22, 354-360, doi: 10.1111/j.1365-3121.2010.00956.x

Le Breton, E., Handy, M., Molli, G., Ustaszewski, K., 2017 Post-20 Ma Motion of the Adriatic 983 Plate: New Constraints From Surrounding Orogens and Implications for Crust-Mantle Decoupling.

Leoni, L., Montomoli, C., Carosi, R., 2009. Il metamorfismo delle unità Tettoniche dei M.Pisani Tectonics 10.1002/2016TC004443

\section{(App. Sett.). Atti Società Toscana Scienze Naturali, Mem. Ser. A 114, 61-73.}

Liotta, D., 2002. D2 asymmetric folds and their vergence meaning in the Montagnola Senese metamorphic rocks (inner northern Apennines, central Italy). Journal of Structural Geology 24, 1479-1490. 
993 Liotta, D., Ranalli, G., 1999. Correlation between seismic reflectivity and rheology in extended 994 lithosphere: southern Tuscany, inner Northern Apennines, Italy Tectonophysics 315, 109-122.

995

Lo Pò, D., Braga, R., Massonne, H.-J., 2016a. Petrographic, mineral and pressure-temperature constraints on phyllites from the Variscan basement at Punta Bianca, Northern Apennines, Italy. Italian Journal of Geosciences 135, 489-502.

Lo Po' D., Braga, R., Massone, H.-J., Molli, G., Montanini, A., Bargossi G.M., 2017. Highpressure tectono-metamorphic evolution of mylonites from Variscan basement from the Northern Apennines, Italy. Journal of Metamorphic Geology doi 10.1111/jmg.12281.

Malavieille J., Molli G., Genti M., Dominguez S., Beyssac O., Taboada A., Vitale Brovarone A., Chia-Lu Y., Chic-Tung Y., 2016. Formation of ophiolite-bearing tectono-sedimentary mélanges in accretionary wedges by gravity driven submarine erosion: Insights from analog models and case studies. Journal of Geodynamics 100, 87-103, doi:10.1016/j.jog.2016.05.008.

Martini I.P., Rau A, Tongiorgi M., 1986. Syntectonic sedimentation in a Middle Triassic rift, Northern Apennines, Italy. Sedimentary Geology 47, 191-219.

Marroni, M., Pandolfi, L., 1996. The deformation history of an accreted ophiolite sequence: the Internal Liguride units (Northern Apennines, Italy). Geodinamica Acta 9, 13-29.

Maxwell, J.C., 1956. Tectonics of Pania della Croce-Pania Secca area, Alpi Apuane. Bollettino della Società Geologica Italiana 75,

Molli, G., 2008. Northern Apennine-Corsica orogenic system: an updated review. In: Siegesmund, S., Fügenschuh, B., Froitzheim, N. (Eds.), Tectonic aspects of the Alpine-Dinaride-Carpathian System Geological Society of London Special Publication 298, 413-442.

Molli G., Meccheri M., 2012 Structural inheritance and style of reactivation at mid-crustal levels: A case study from the Alpi Apuane (Tuscany, Italy). Tectonophysics 579 74-87 doi:10.1016/j.tecto.2012.06.044.

Molli, G., Vaselli, L., 2006. Structures, interference patterns and strain regime during mid-crustal 
deformation in the Alpi Apuane (Northern Apennines, Italy). In: Mazzoli, S., Butler, R. (Eds.), Styles of continental contraction Geological Society of America Special Papers 414, 79-93.

Molli, G., Conti, P., Giorgetti, G., Meccheri, M., and Oesterling, N., 2000a, Microfabric studies on the deformational and thermal history of the Alpi Apuane marbles (Carrara marbles), Italy. Journal of Structural Geology, 22, 1809-1825, doi:10.1016/S0191-8141(00)00086-9.

Molli, G., Giorgetti, G., Meccheri, M., 2000. Structural and petrological constraints on the tectonometamorphic evolution of the Massa Unit (Alpi Apuane, NW Tuscany, Italy). Geological Journal 35, 251-264.

Molli, G., Giorgetti, G., Meccheri, M., 2002. Tectono-metamorphic evolution of the Alpi Apuane Metamorphic Complex: new data and constraints for geodynamic models. Bollettino Società Geologica Italiana 1, 789-800.

Molli, G., White, J.C., Kennedy, L., and Taini, V., 2011. Low-temperature deformation of limestone, Isola Palmaria, Northern Apennine, Italy-The role of primary textures, precursory veins and intracrystalline deformation in localization. Journal of Structural Geology 33, 255-270, doi: 10 $.1016 / j$.jsg .2010.11.015.

Molli G., 2012. Deformation and fluid flow during underplating and exhumation of the Adria continental margin: A one-day field trip in the Alpi Apuane (northern Apennines, Italy). The Geological Society of America Field Guide 28, 35-48.

Molli G., Doveri M., Manzella A., Bonini L., Botti F., Menichini M., Montanari D., Trumpy E., Ungari A., Vaselli L., 2015. Surface-subsurface structural architecture and groundwater flow of the Equi Terme hydrothermal area, Northern Tuscany Italy, Italian Journal Geosciences, doi 10.3301/IJG.2014.25

Molli G., Torelli L., Storti F., 2016. The 2013 Lunigiana (Central Italy) earthquake: Seismic source analysis from DInSar and seismological data, and geodynamic implications for the northern Apennines. A discussion. Tectonophysics, 668-669, 108-112.

Montomoli, C., Ruggieri, G., Boiron, M.C., Cathelineau, M., 2001. Pressure fluctuation during 
1061 uplift of the Northern Apennines (Italy): a fluid inclusion study. Tectonophysics 341, 121-139.

1062

1063

1064

1065

1066

1067

1068

1069

1070

1071

1072

1073

1074

1075

1076

1077

1078

1079

1080

1081

1082

1083

1084

1085

1086

1087

1088

1089

1090

1091

1092

1093

1094

1095

Montomoli, C., 2002. Evoluzione termobarica del complesso metamorfico dei Monti Pisani (Appennino Settentrionale) e inclusioni fluide: dati preliminari. Atti Società Toscana Scienze Naturali, Serie A, 108, 21-26.

Montomoli, C., 2002. Vein development and fluid inclusion data: insight on the evolution of the Tuscan Nappe in the Northern Apenines. Bolletino Società Geologica Italiana Volume Speciale 1, 801-817.

Musumeci, G., Mazzarini, F., Cruden, A.R. 2015. The Zuccale Fault, Elba Island, Italy: A new perspective from fault architecture Tectonics, 34, 1195-12018, 10.1002/2014TC003809

Nardi, E., 1961. Geologia della zona tra la Pania della Croce, Gallicano e Castelnuovo Garfagnana (Alpi Apuane). Bollettino della Societa Geologica Italiana 80, 1-18.

Oesterling, N., Heilbronner, R., Stünitz, O., Barnhoorn, A., Molli, G. 2007. Strain dependent variation of microstructure and texture in naturally deformed Carrara marble. Journal of Structural Geology, 29, 681-696.

Pandeli, E., Gianelli, G., Puxeddu, M., Elter, F.M., 1994. The Paleozoic basement of the Northern Apennines: stratigraphy, tectono-metamorphic evolution and alpine hydrothermal processes. Memorie della Società Geologica Italiana 48, 627-654.

Paoli, G., Stokke, H.H., Rocchi, S., Sirevaag, H., Ksienzyk, A.K., Jacobs, J., Košler, J., 2017. Basement provenance revealed by $\mathrm{U}-\mathrm{Pb}$ detrital zircon ages: A tale of African and European heritage in Tuscany, Italy. Lithos 277, 376-387.

Patacca, E., Scandone, P., Conti, P., Mancini, S., Massa, G., 2013. Ligurian-derived olistostrome in the Pseudomacigno Formation of the Stazzema Zone (Alpi Apuane, Italy). Geological implications at regional scale. Italian Journal Geosciences, 132 (3), 463-476. doi: 10.3301/IJG.2013.05.

Pauselli, C. Federico, C., 2005. Extensional regime in the Northern Apennines: indications from the lithospheric behaviour. Bollettino di Geofisica Teorica ed Applicata 47, 1-2, 73-87. 
1096 Platt J.P., Soto J-I., Whitehouse M.J., Hurford A.J., Kelley S.P., 1998. Thermal evolution, rate of 1097 exhumation, and tectonic significance of metamorphic rocks from the floor of the Alboran 1098 extensional basin, western Mediterranean. Tectonics 17, 671-89.

Rahl, J.M., Anderson, K.M., Brandon, M.T., Fassoulas, C., 2005. Raman spectroscopic carbonaceous material thermometry of lowgrade metamorphic rocks: calibration and application to tectonic exhumation in Crete, Greece. Earth Planet Science Letters 240, 339-354.

Rau A, Tongiorgi M., 1974. La geologia dei Monti Pisani a Sud-Est della Valle del Guappero. Memorie Societa Geologica Italiana 13, 227 - 408.

Reutter, K.J., Teichmuller, M., Teichmuller, R., Zanaucchi, G., 1978. Coalification studies in the 1108 Northern Apeninnes and paleogeothermal implications. In: Closs, H., Roeder, D., Schmidt, K. 1109 (Eds.), Alps, Apennines and Hellenides.Schweizerbartsche Verlagbuchhandlung, Stuttgart, 261267.

1112 Reutter, K., Teichmuller, M., Teichmuller, R., Zanzucchi, G., 1983. The coalification pattern in the 1113 Northern Apennines and its paleogeothermic and tectonic significance. Geologische Rundschau 72, 1114 861-894.

1116 Ring, U., Brandon, M. T., Willet, S. D., Lister, G. S., 1999. Exhumation processes. In: Ring, U., 1117 Brandon, M. T., Lister, G. S., and Willet, S. D., eds., Exhumation processes: Normal faulting, 1118 ductile flow and erosion. Geological Society of London Special Publication, 154, 1-27.

1120 Rosenberg, C.L., Berger, A., Bellhasen, N., Bousquet, R., 2015. Relating orogen width to 1121 shortening, erosion, and exhumation during Alpine collision. Tectonics, 10.1002/2014TC003736.

Scharf, A., Handy, M.R., Ziemann, M.A., Schmid, S.M., 2013. Peak-temperature patterns of polyphase metamorphism resulting from accretion, subduction and collision (eastern Tauern 1125 Window, European Alps) - a study with Raman microspectroscopy on carbonaceous material (RSCM). Journal of Metamorphic Geology, doi: 10.1111/jmg.12048

1128 Selverstone J. 1988. Evidence for east-west crustal extension in the Eastern Alps implications for 1129 the unroofing history of the Tauern Window. Tectonics, 7, 87-105 
1131 Simoes, M., Avouac, J.P., Beyssac, O., Goffe, B., Farley, K.A. and Chen, Y.-G., 2007. Mountain 1132 building in Taiwan: a thermokinematic model. Journal of Geophysical Research, 112, B11405.

1134 Schmid, S.M., Kissling, E., Dihel, T., van Hinsbergen D.J.J., Molli, G. 2017. Ivrea mantle wedge, 1135 arc of the Western Alps, and kinematic evolution of the Alps-Apennines orogenic system, Swiss 1136 Journal of Geosciences (2017) 110, 581-612, doi: 10.1007/s00015-016-0237-0

Spada, M., Bianchi I., Kissling, E., Piana Agostinetti, A., Wiemer, S. 2013. Combining controlled1139 source seismology and receiver function information to derive 3-D Moho topography for Italy 1140 Geophys. J. Int., 194 2(1) 1050-1068, doi:10.1093/gji/ggt148.

Storti F. 1995. Tectonics of the Punta Bianca promontory: Insights for the evolution of the Northern Apennines-Northern Tyrrhenian Sea basin. Tectonics, 14, 832-847.

Thomson, S.N., Brandon, M.T., Reiners, P.W., Zattin, M., Isaacson P.J., Balestrieri, M.L. 2010. 1146 Thermochronologic evidence for orogen-parallel variability in wedge kinematics during extending 1147 convergent orogenesis of the northern Apennines, Italy. Geological Society America Bulletin 122, $1148 \quad 7-8,1160-1179$.

Ventura, B., Pini, G.A., Zuffa, G.G. 2001. Thermal history and exhumation of the Northern Apennines Relationship between Tmax and clay minerals (Italy): evidence from combined apatite fission track and vitrinite reflectance data from foreland basin sediments. Basin Research, 13, 4351153448. Verdoya, M., Pasquale, V., Chiozzi, P. 2005. Thermo-mechanical evolution and rheology of the northern sector of the Tyrrhenian-Apennines system. Journal of Volcanology and Geothermal Research 148, 20-30.

Vitale Brovarone A., Beyssac O., Malavieille J., Molli G., Beltrando M., Compagnoni R., 2013. 1160 Stacking and metamorphism of continuous segments of subducted lithosphere in a high-pressure 1161 wedge: The example of Alpine Corsica (France). Earth-Science Reviews 116, 35-56, 1162 doi.org/10.1016/j.earscirev.2012.10.003. 
1164 Vitale Brovarone, A., Picatto, M., Beyssac, O., Lagabrielle, Y., Castelli, D., 2014. The blueschist1165 eclogite transition in the Alpine chain: PT paths and the role of slow-spreading extensional 1166 structures in the evolution of HP-LT mountain belts. Tectonophysics 615-616, 96-121.

1167 Wiederkehr, M., Bousquet, R., Ziemann, M. A., Berger, A., Schmid, S. M. 2011. 3-D assessment of 1168 peak-metamorphic conditions by Raman spectroscopy of carbonaceous material: An example from 1169 the margin of the Lepontine dome (Swiss Central Alps). International Journal of Earth Sciences 1170 100(5), 1029-1063.

1171 Zattin, M., Picotti, V., Zuffa, G.G., 2002. Fission-track reconstruction of the front of the Northern 1172 Apennine thrust wedge and overlying Ligurian Unit. American Journal of Science 302, 346-379. 
Figures caption

1177 Fig.01. Geological setting of the Northern Apennines and regional cross sections (mod. by Molli, 1178 2008) with indicated the studied areas.

1179 Fig.02. Tectonic map of the inner Northern Apennines with locations of analyzed samples. In the 1180 figure are also reported previous Temperature data sets and related references. For illite cristallinity 1181 data grey and black values are related respectively to the Scaglia fm. (Late Cretaceous-Oligocene) 1182 and Calcari a Rhaetavicula Contorta Fm. (Late Trias).

1183 Fig.03 Examples of spectra RSCM of selected analyzed samples. To be noticed as significant 1184 differences in the spectra correspond to slight differences in peak temperatures.

1185 Fig.04 Geological map of the Alpi Apuane with measured RSCM temperatures and other data 1186 available from literatures: (1) Ca/Do from in Molli et al. 2000; (2) Di Pisa et al. 1985.

1187 Fig.05 Cross-sections across the Alpi Apuane with RSCM temperatures

1188 Fig.06. a) Cross section of La Spezia area and measured RSCM temperatures; b) Stratigraphy and 1189 RSCM temperatures in the Tuscan Nappe.

1190 Fig.07 RSCM temperatures in the different tectonic units of the Alpi Apuane and nearby 1191 metamorphic core of Punta Bianca and Monte Pisano. The vertical position of the samples 1192 correspond to the distance from the reference surface represented by the basal contact of Tuscan 1193 Nappe (see scal bar in meters).

1194 Fig.08 Stratigraphy and RSCM temperatures in the Apuane unit.

1195 Fig.09. Paleothermal and structural architecture of the Alpi Apuane metamorphic core complex. a) 1196 structural architecture of the Alpi Apuane metamorphic core; b) window-scale paleothermal 1197 architecture; c) paleothermal architecture in cross-sections view.

1198 Fig.10. Evolutionary model for the Alpi Apuane within the different stages of Apenninic wedge 1199 growth from crustal thickening to crustal thinning stages (* Kligfield et al., 1986; ** Giglia, 1200 Radicati di Brozolo, 1974; *** Fellin et al., 2007 and references): a) early stage of nappe stacking 1201 below the Ligurian/subligurian lid (former accretionary wedge); b) the same as in a) with in red 1202 dashed lines the $400^{\circ}, 350^{\circ}$ and $300^{\circ} \mathrm{C}$ paleoisotherms; c,d) successive duplexing stage with 1203 formation of internal stacking and overthrusting of Massa (higher grade) above the Apuane unit 1204 (lower grade). During this deformation path, a folding of previous paleoisotherms is envisiged to 1205 produce the thermal features described at pages 10-11 (see cross sections E,F,I of Figs. 4,5 and 1206 Fig.9). In blue the possible path way of hot fluids coming from subducted middle to lower crust 1207 which may be associated with ore bodies, reworked within the Stazzemese Shear zone during 
1208 following deformation stages; e) antiformal stacking phase with development of: 1) finite geometry 1209 of regional deformation structures (dome shape of main foliation and related regional D1 structures) 1210 and 2) the finite thermal structure with the regional folding of previous isotherms (f); g), h) 1211 switching from crustal thickening to crustal thinning with development of D2 structures related to a 1212 vertical shortening accounting for a minimum of $20 \%$ of distributed ductile thinning (see Molli and 1213 Vaselli, 2007), as well as the "Stazzemese Shear Zone", which is the possible deeper expression of 1214 a linked extensional detachment system including the brittle "window fault". The activity of the 1215 "window fault" continued up to crustal depth corresponding to an ambient temperature of $180{ }^{\circ} \mathrm{C}$ 1216 (see thermochronological data in Fellin et al., 2007; i) and 1) final stages of exhumation (4-5 Km of 1217 vertical displacement) of the Alpi Apuane metamorphic core in a crustal thinning stage starting 1218 from 7-5 Ma (Ap Ft Fellin et al., 2007 and references) and continuing up to now (Bennett et al., 1219 2012; Molli et al., 2016). During this stage, deformation is accommodated by high angle normal to 1220 transtensive faults cross cutting the "window fault" as well as the syn-metamorphic templates. In 1) 1221 isotherms are drawn according to thermal data and modeling in Verdoya et al., 2005; Pauselli et al., 1222 2006; Faccenda et al., 2009.

1224 Table 1. Selected samples for RSCM thermometry. GPS coordinates in WGS84 system, number of 1225 spectra (n), mean R2ratio (Beyssac et al., 2002a) or RA1 ratio (Lahfid et al., 2010) for n spectra 1226 with corresponding standard deviation (sdv), and calculated temperature with standard error (SE). 1227 Standard error is the standard deviation divided by $\sqrt{\mathrm{n}}$. The absolute error on temperature is \pm 50 1228 C (Beyssac et al., 2002a). *low-T samples processed with RA1 ratio. ** Samples for which the 1229 degree of graphitization of $\mathrm{CM}$ might reflect hydrothermal processes rather than regional 1230 metamorphism. 


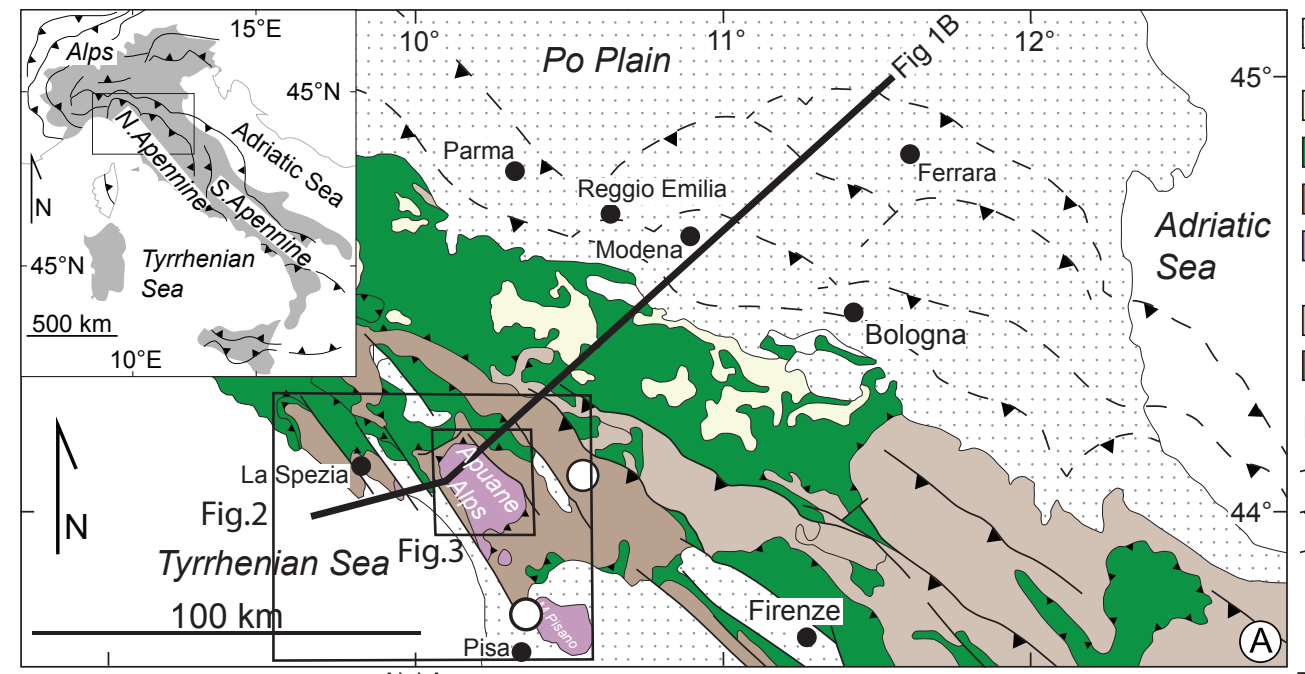

Neogene and Quaternary sediments

$\square$ Epiligurian top-wedge sediments

Ligurian units

Tuscan Nappe

Tuscan Metamorphic units and

Tuscan basement

"External" sedimentary units

"External" basement units

Major faults

$\longrightarrow$ Thrust fault at surface

$\sim$ Thrust fault in subsurface

High angle normal and trascurrent faults

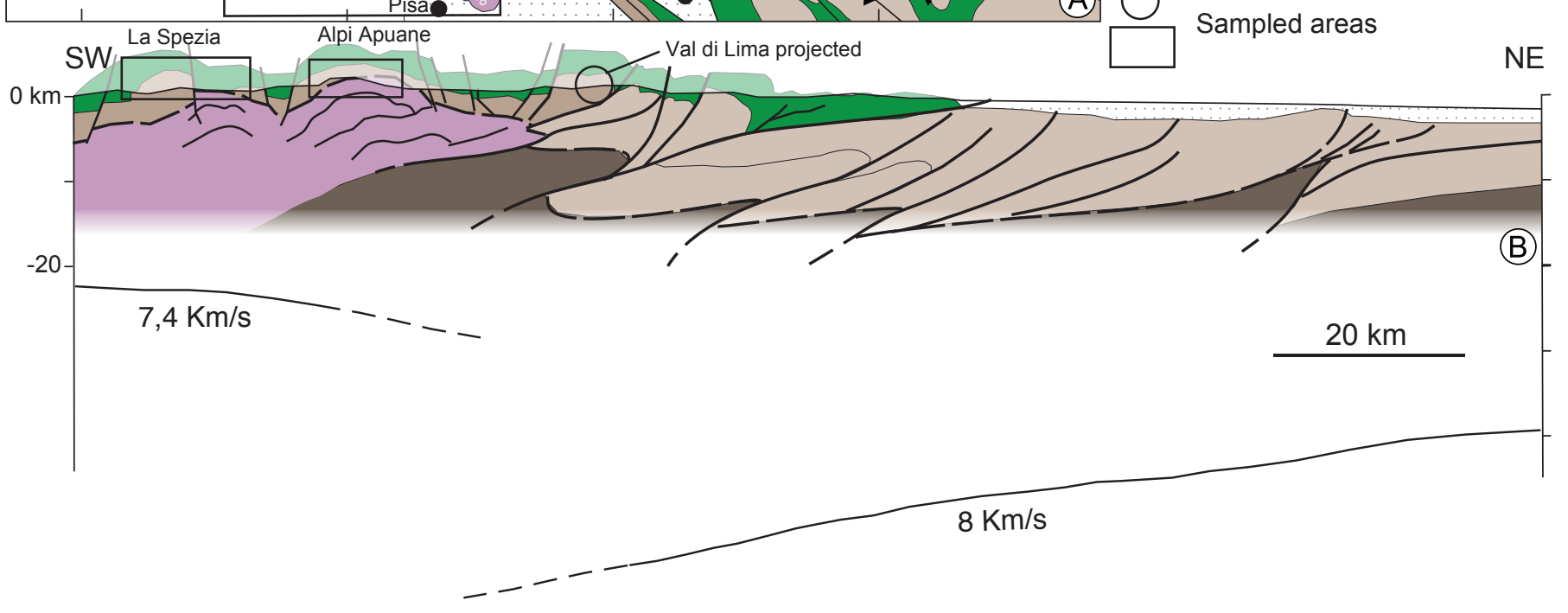

Fig.01 Molli et al., JSG

Fig.01. Geological setting of the northern Apennines and regional cross sections (mod. by Molli, 2008) with indicated the studied areas. 
Fig.02 Molli et al., JSG

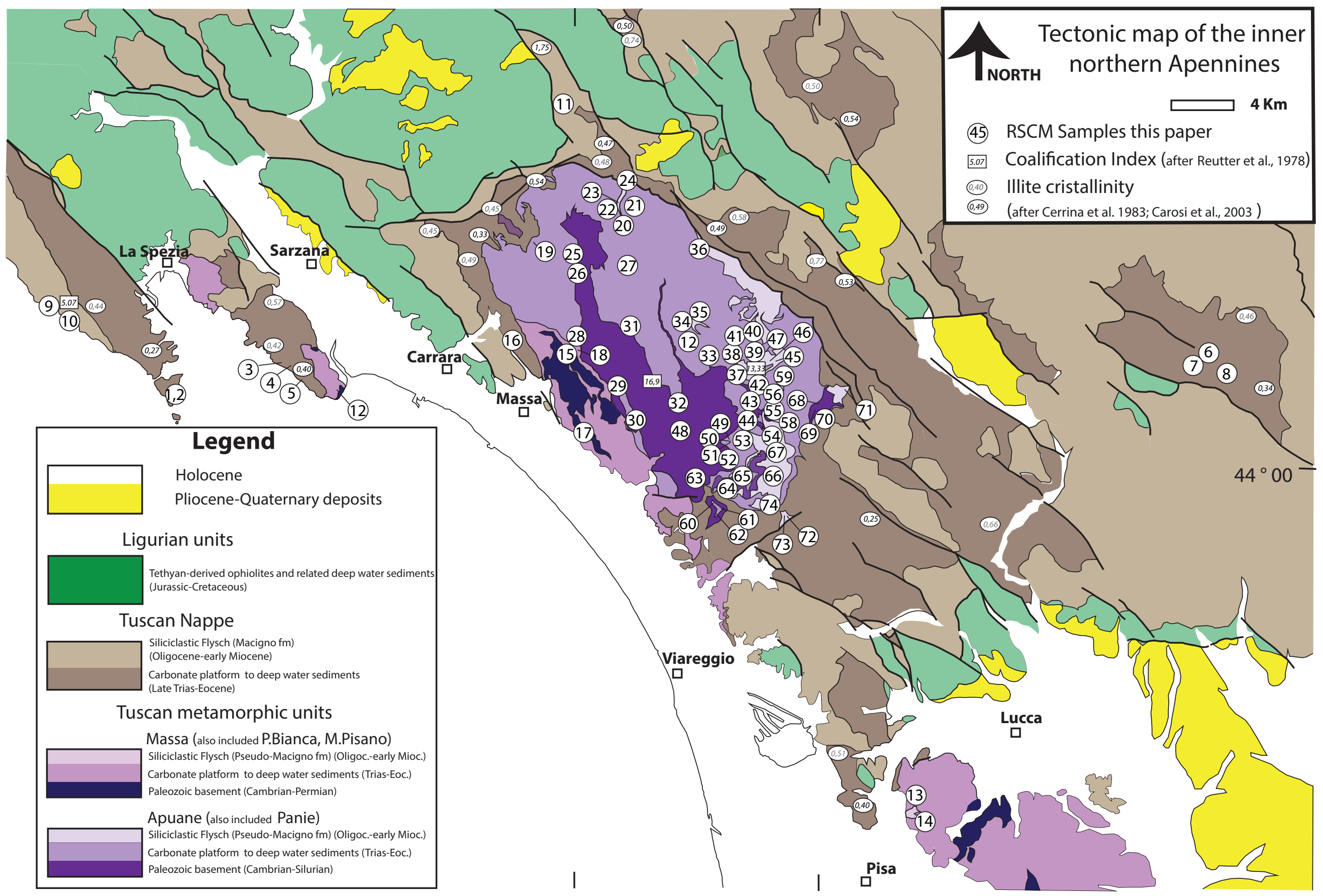

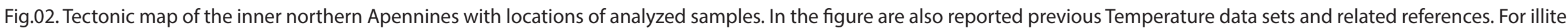
cristallinity data grey and black values are related respectively to the Scaglia fm. (Late Cretaceous-Oligocene) and Calcari a Rhaetavicula Contorta Fm. (Late Trias). 

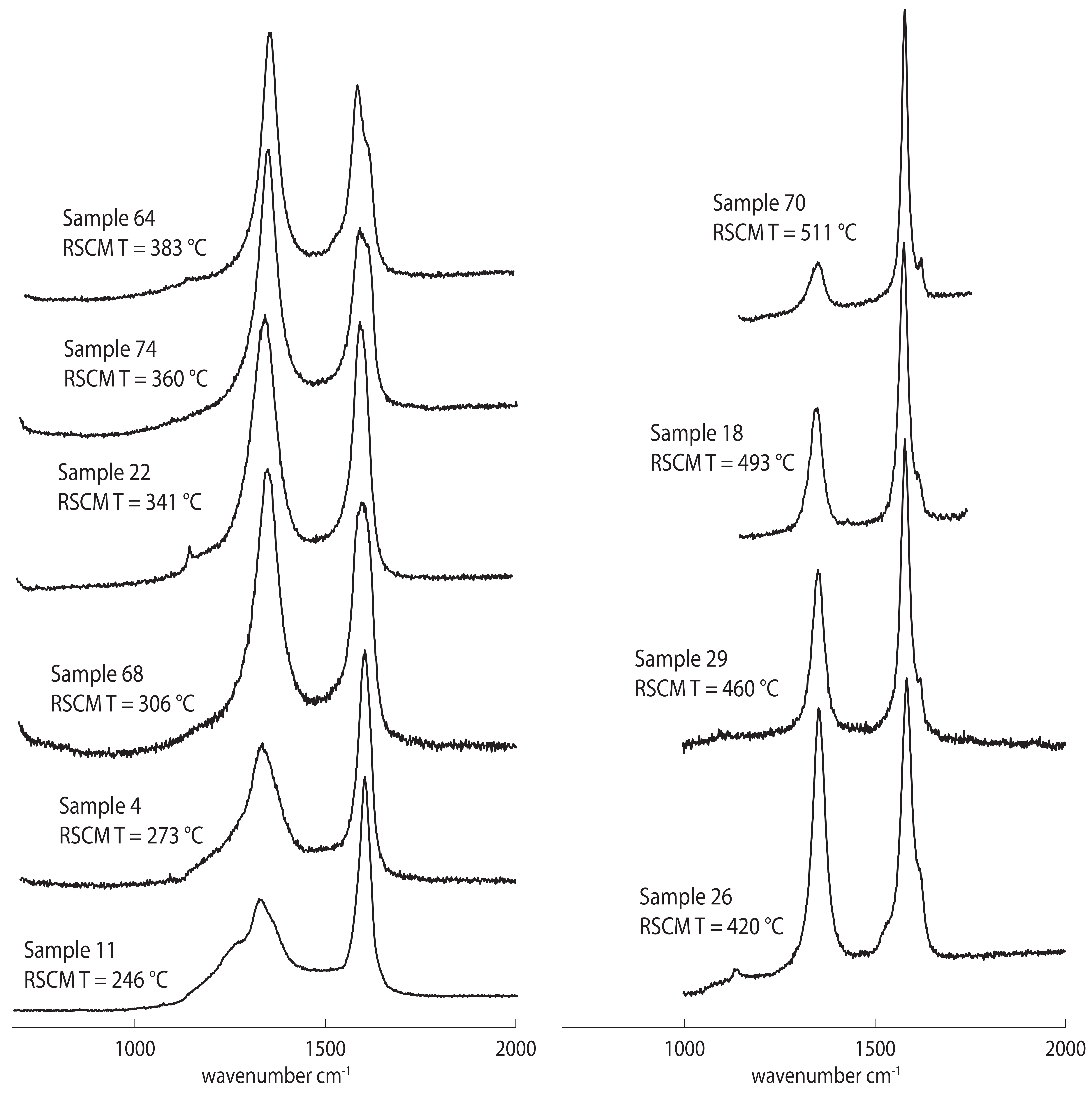

Fig.03 Examples of spectra RSCM of selected analyzed samples. To be noticed as significant differences in the spectra correspond to slight differences in peak temperatures.

Molli et al JSG 


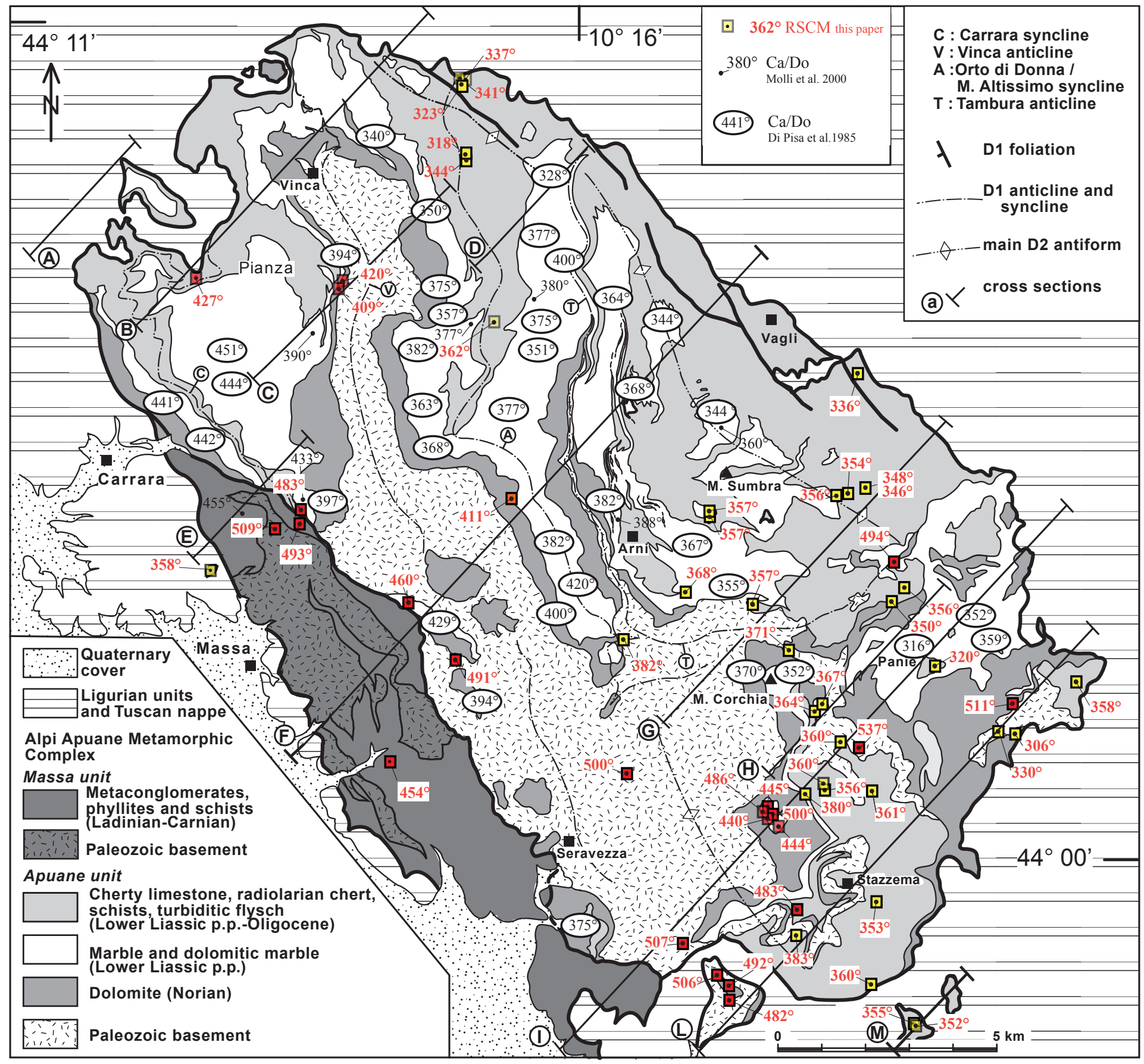

Fig.04 Molli et al. JSG

Fig.04 Geological map of the Alpi Apuane with measured RSCM temperatures and other data available from literatures: Ca/Do from in Molli et al. 2000; Di Pisa et al. 1985. 


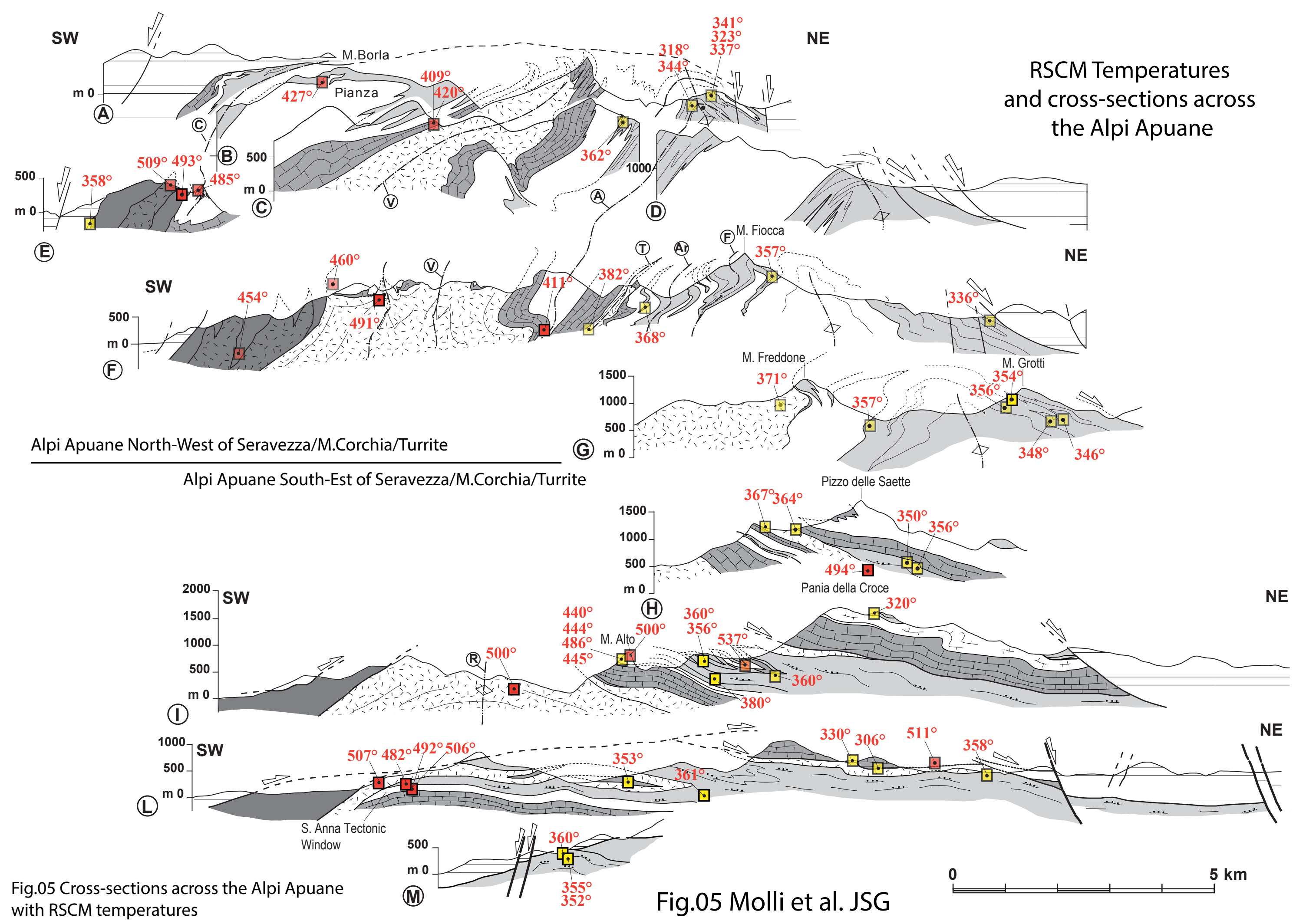




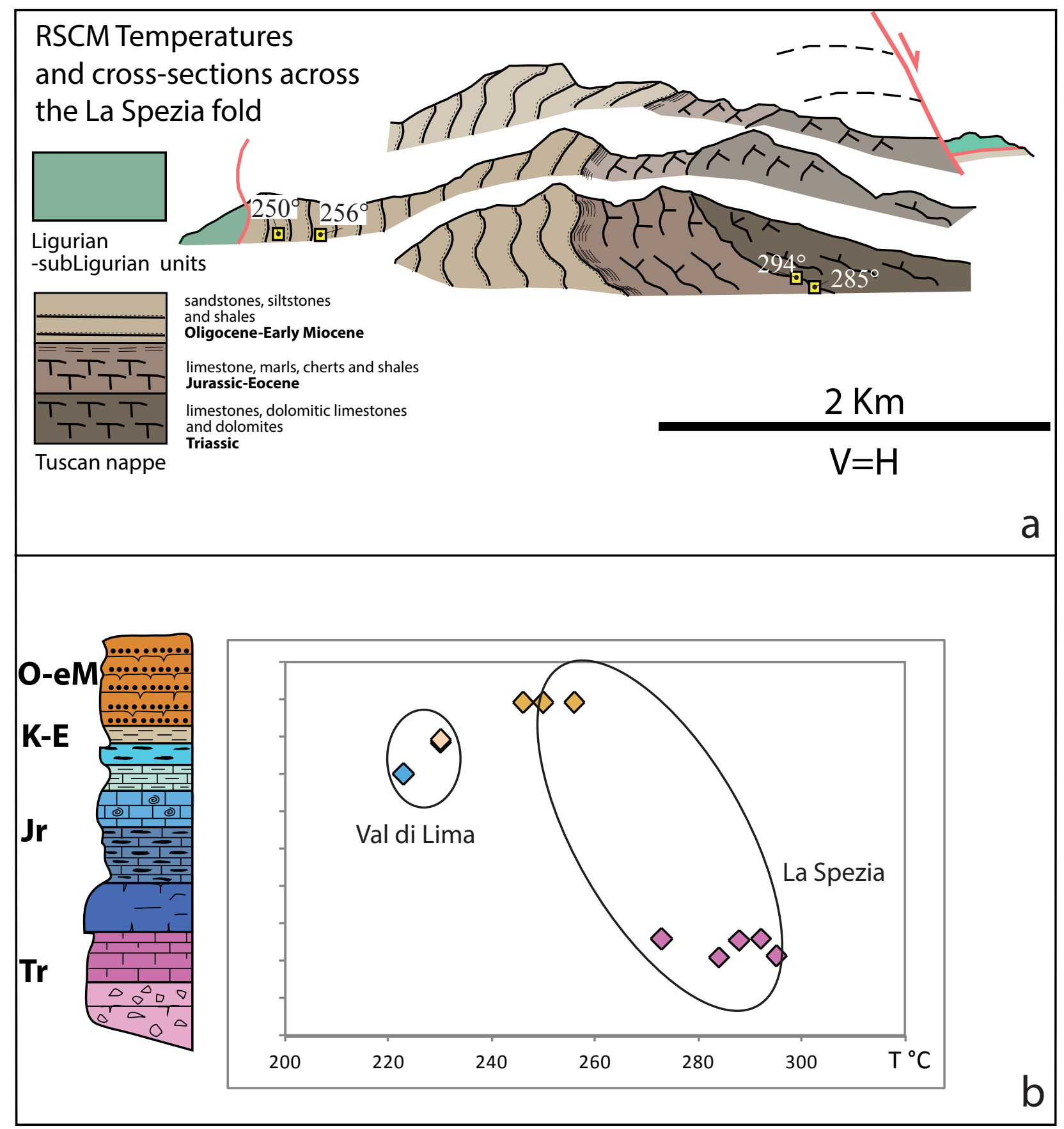

Fig. 06 Molli et al JSG

Fig.06. a) Cross section of La Spezia area and measured RSCM temperatures;

b) Stratigraphy and RSCM temperatures in the Tuscan Nappe. 


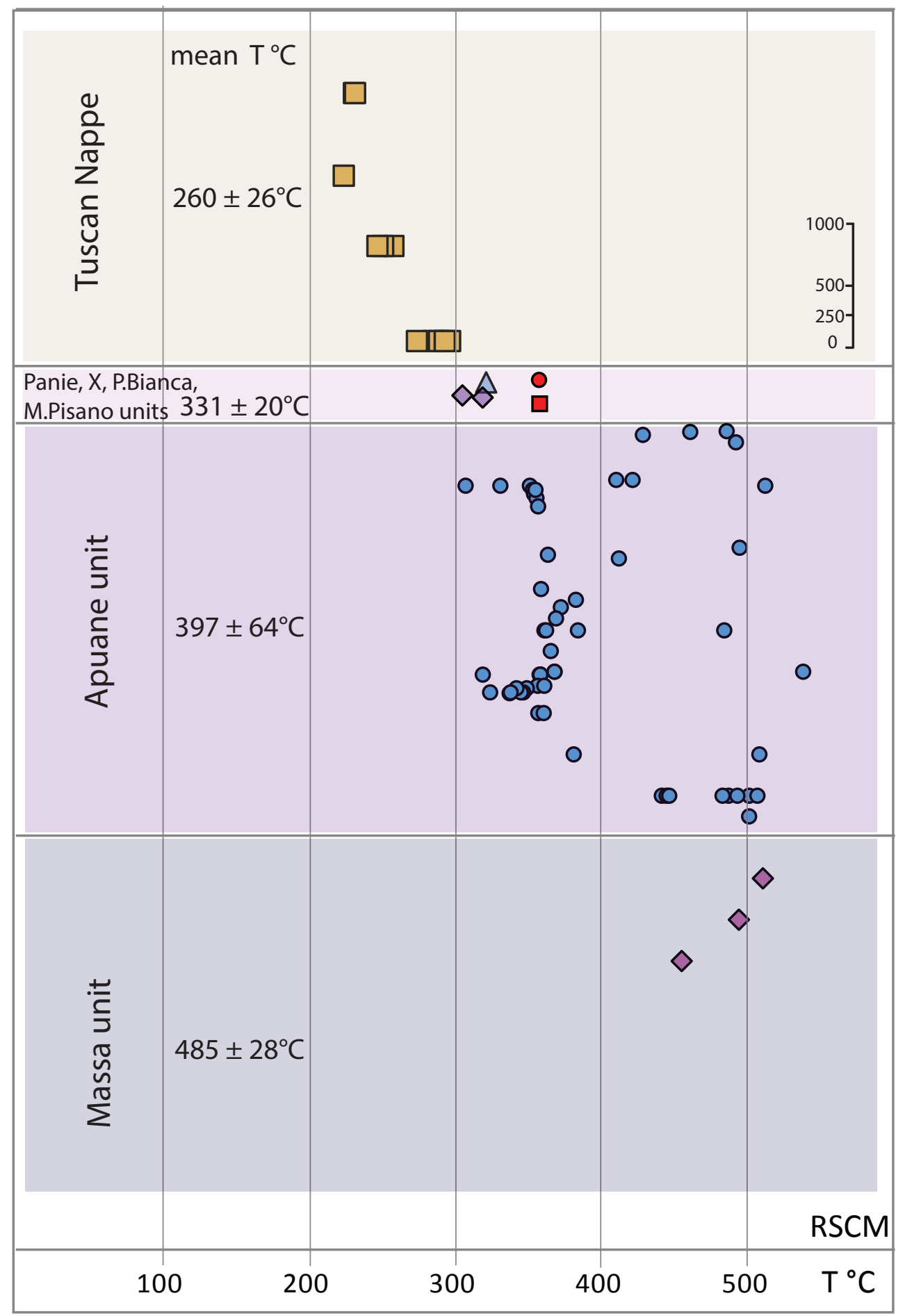

Fig07 Molli et al., JSG

Fig.07 RSCM temperatures in the different tectonic units of the Alpi Apuane and nearby metamorphic core of Punta Bianca and Monte Pisano. The vertical position of the samples correspond to the distance from the reference surface represented by the basal contact of Tuscan Nappe (see scal bar in meters). 

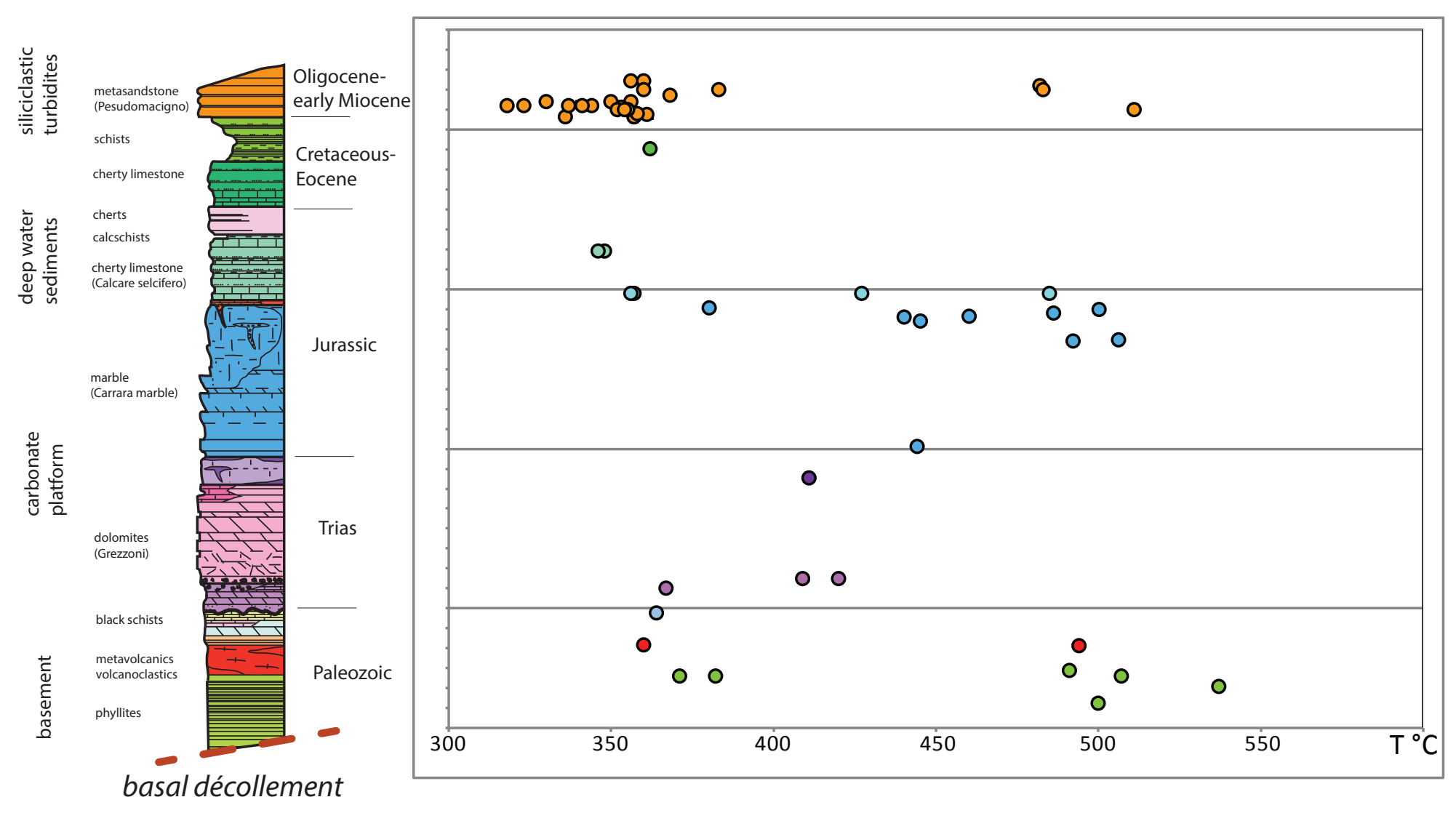

Fig08 Molli et al., JSG

Fig.08 Stratigraphy and RSCM temperatures in the Apuane unit. 
Paleothermal and structural architecture of the Alpi Apuane metamorphic core

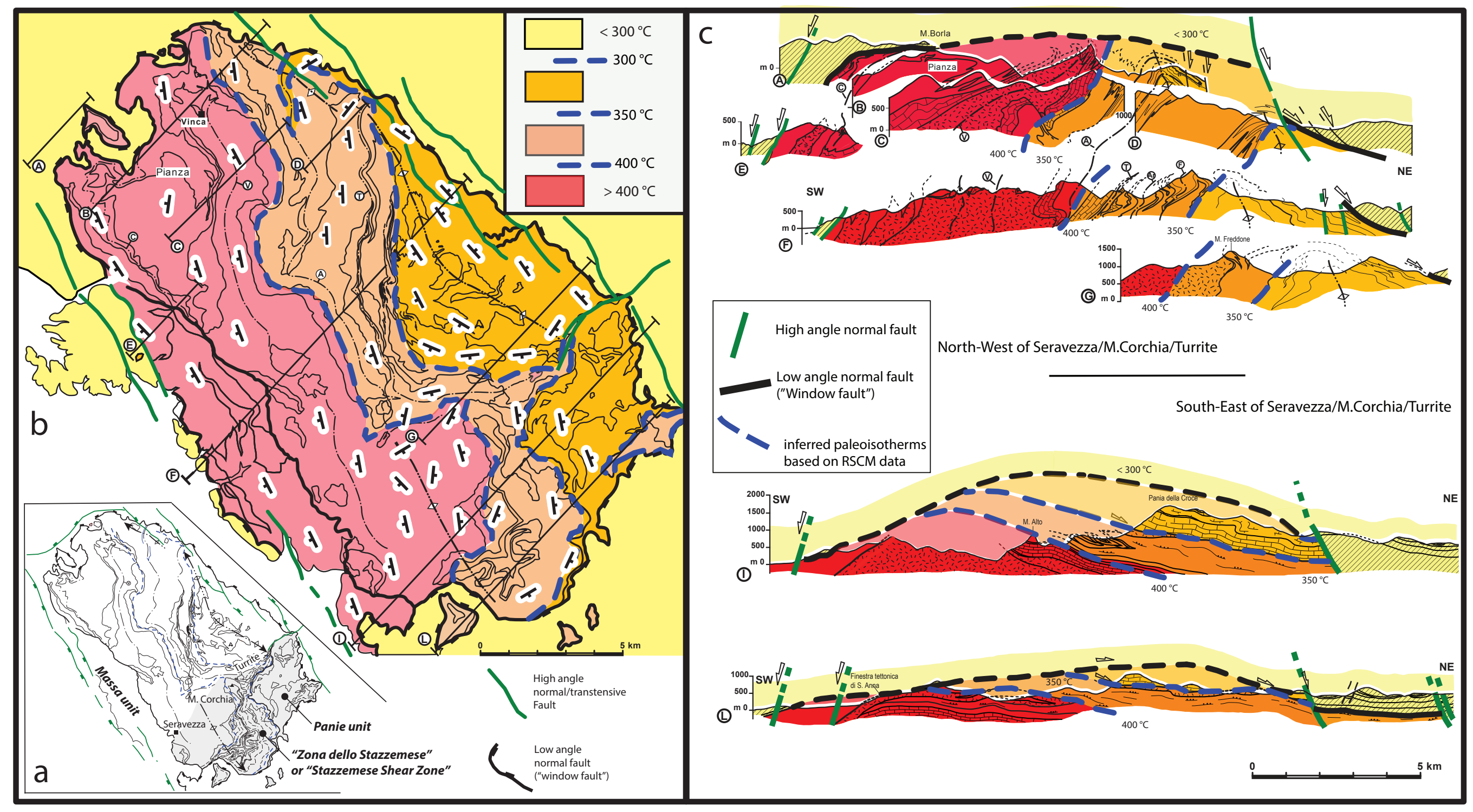

Fig. 09 Molli et al JSG

Fig.09. Paleothermal and structural architecture of the Alpi Apuane metamorphic core complex. a) structural architecture of the Alpi Apuane metamorphic core; b) window-scale paleothermal architecture; c) paleothermal architecture in cross-sections view. 


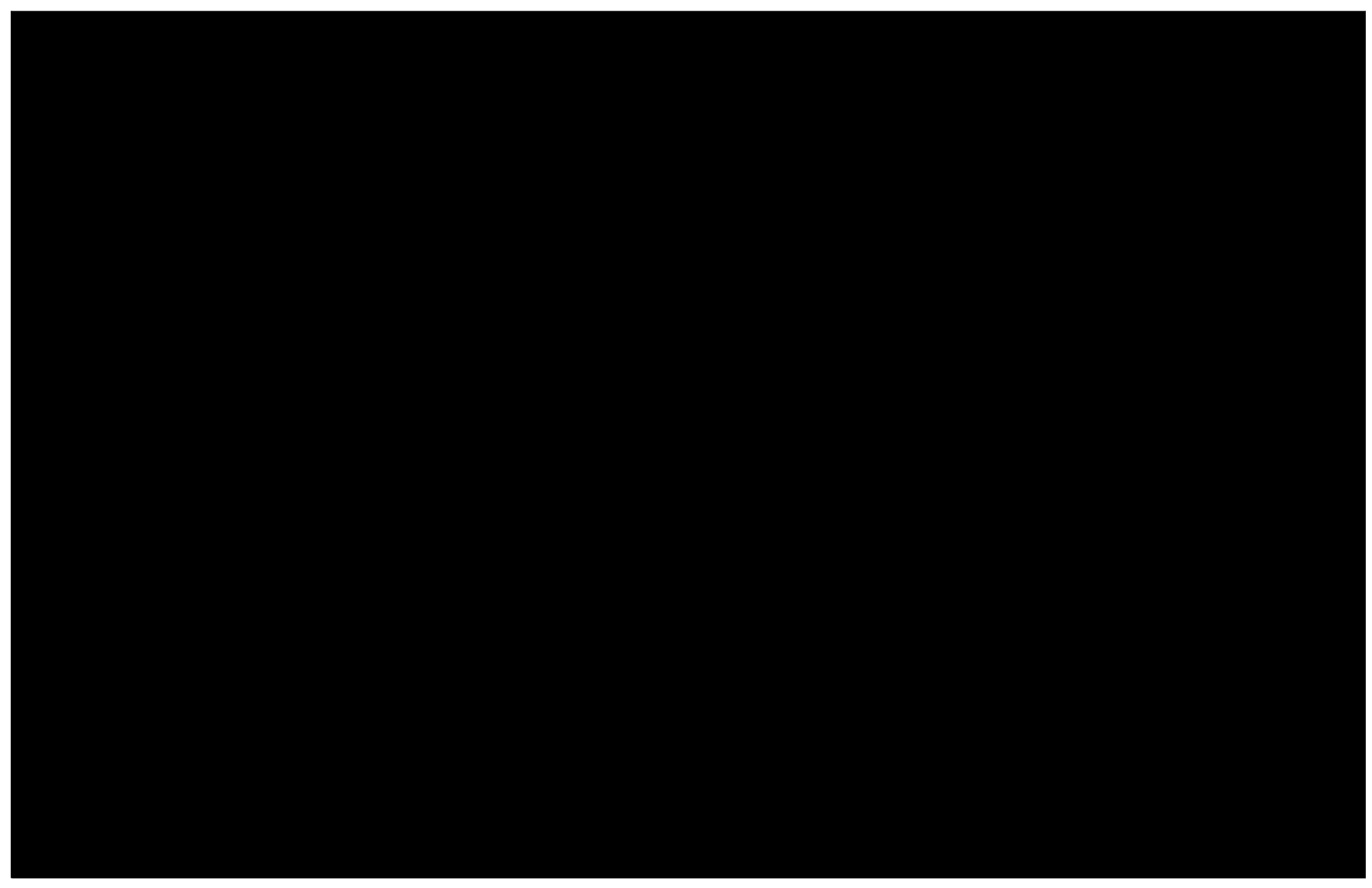

